University of Arkansas, Fayetteville

ScholarWorks@UARK

\title{
The Competitive Effects of the Louisiana Scholarship Program on Public School Performance
}

Anna J. Egalite

North Carolina State University

Follow this and additional works at: https://scholarworks.uark.edu/scdp

Part of the Education Policy Commons, Public Policy Commons, and the Social Policy Commons

\section{Citation}

Egalite, A. J. (2016). The Competitive Effects of the Louisiana Scholarship Program on Public School Performance. School Choice Demonstration Project. Retrieved from https://scholarworks.uark.edu/scdp/ 19

This Report is brought to you for free and open access by the Education Reform at ScholarWorks@UARK. It has been accepted for inclusion in School Choice Demonstration Project by an authorized administrator of ScholarWorks@UARK. For more information, please contact scholar@uark.edu. 


\section{THE COMPETITIVE EFFECTS OF THE LOUISIANA SCHOLARSHIP PROGRAM ON PUBLIC SCHOOL PERFORMANCE}

\section{EDUCATION RESEARCH ALLIANCE}

FOR NEW ORLEANS

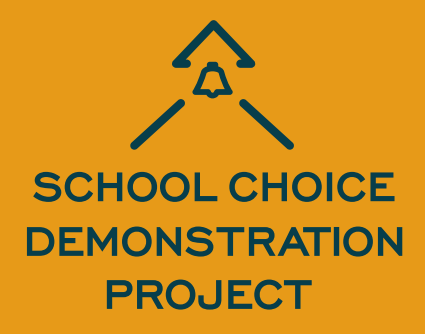

PROJECT

Anna J. Egalite

February 22, 2016

Education Research Alliance NOLA.com

UAedreform.org/school-choice-demonstration-project 


\title{
THE COMPETITIVE EFFECTS OF THE LOUISIANA SCHOLARSHIP PROGRAM ON PUBLIC SCHOOL PERFORMANCE
}

\author{
Anna J. Egalite \\ Department of Educational Leadership, Policy, and Human Development \\ North Carolina State University \\ Raleigh, NC, 27695 \\ Anna_Egalite@ncsu.edu
}

Louisiana Scholarship Program Evaluation Report \#4

February 2016

School Choice Demonstration Project, University of Arkansas, Fayetteville, AR Education Research Alliance, Tulane University, New Orleans, LA

\footnotetext{
Acknowledgments

I gratefully acknowledge the Smith Richardson Foundation for financial support for this research. The content of the report is solely the responsibility of the author and does not necessarily represent the views of the Smith Richardson Foundation, North Carolina State University, University of Arkansas, or Tulane University. I am also grateful to Patrick J. Wolf, Jay P. Greene, Robert M. Costrell, Kate Dougherty, Jonathan N. Mills, and Douglas N. Harris, for their extensive helpful comments on previous drafts and the Louisiana Department of Education for their cooperation and assistance with providing the necessary data to conduct the analyses.
} 


\title{
The Competitive Effects of the Louisiana Scholarship Program on Public School Performance
}

\begin{abstract}
Given the significant growth rate and geographic expansion of private school choice programs over the past two decades, it is important to examine how traditional public schools respond to the sudden injection of competition for students and resources. This article uses 1) a school fixed effects approach, and 2) a regression discontinuity framework to examine the achievement impacts of the Louisiana Scholarship Program (LSP). This targeted school voucher program has provided public funds for low-income students in low-performing public schools to enroll in participating private schools since the 2012-13 school year. The main findings of the competitive effects analysis reveal neutral to positive impacts that are small in magnitude. Effects are largest for students attending those public schools most affected by the competitive threat. Policy implications are discussed.
\end{abstract}

Keywords: competition; school vouchers; school choice; systemic effects 


\section{The Competitive Effects of the Louisiana Scholarship Program on Public School Performance}

\section{Introduction}

Publicly funded private school choice programs currently operate in twenty states plus the District of Columbia (Frendewey et al., 2015). Much of this growth in private school choice programs has been recent, with the total number of programs in operation nationwide increasing from 32 to 39 in 2013-14 alone. Given the significant growth rate and geographic expansion of private school choice programs over the past two decades, how should we expect traditional public schools to respond to the competition? In this article, I exploit variation in the geographic location of private schools in Louisiana to estimate the competitive impact of a private school choice program on public school math and English language arts achievement.

The Louisiana Scholarship Program (LSP) is a targeted school voucher program that provides public funds for low-income students in low-performing public schools to enroll in participating private schools, both religious and non-religious. Initially piloted in New Orleans in 2008, Act 2 of the 2012 Regular Session expanded the LSP statewide, allowing thousands of public school students to transfer out of their residentially-assigned public schools and into private schools across the state of Louisiana. In order to be eligible for a voucher, a student's family income must not have exceeded $250 \%$ of the federal poverty guidelines and they must have been entering Kindergarten or coming from a public school that received a "C," "D," or "F" grade in October 2011. In school year 2012-13, 9,831 eligible Louisiana students applied for an LSP voucher. Ultimately 4,954 students from low-performing public schools used these vouchers to enroll in private schools. All of these students were low-income and approximately 80 percent were African American. The value of the scholarship varied by school, depending on 
the tuition and fees at each participating private school, but it was capped at the amount the state expends on public education through its minimum foundation program. Thus, the average value of an LSP scholarship in 2012-13 was $\$ 5,245$, which was approximately $\$ 3,000$ dollars less than what it cost to send a student to a "C," "D," or "F" graded public school that year.

While all Louisiana private schools experienced some degree of private school competition prior to 2012-13, the statewide expansion of the program constituted a policy shock that arguably increased the competitive pressure experienced by all public schools. For those public schools graded "C," "D," or "F" this shock would have been especially salient, as their students suddenly became eligible to transfer to a private school alternative at state expense. Using an identification strategy that relies on this distinction between eligible and ineligible public schools, I exploit the timing of the voucher policy in Louisiana to estimate the public school response to private school competition. While the observed impacts are small, three out of four competition measures reveal a positive, statistically significant impact on public school math scores and two out of four competition measures reveal a positive and statistically significant impact on English Language Arts scores.

The remainder of this article proceeds as follows. First, I put the LSP in context by presenting statistics on the set of all private school choice programs that currently exist in the United States. I then describe the theoretical framework, followed by a summary of the literature on the competitive impacts of private school choice programs. The next section describes the data and research design used in this analysis, followed by a presentation of the results. The article concludes with a summary of the main findings and a discussion of the policy implications. 


\section{Private School Choice Programs in the U.S.}

By June 2015, 45 private school choice programs had been enacted in the U.S. in 23 states plus the District of Columbia (Table 1). In absolute terms, the two largest voucher programs are Florida’s John M. McKay Scholarship for Students with Disabilities Program and Indiana's Choice Scholarship Program. Nonetheless, these enrollment figures pale in comparison to those associated with the largest tax credit scholarship program—Florida's Tax Credit Scholarship program — which enrolled close to 70,000 students in 2014-15, representing almost two percent of all children in that state. The Louisiana Scholarship Program is not unusual in that it targets low-income families, joining 23 other private school choice programs that require applicants' family income to fall below a given threshold in order for a student to be eligible to participate. With 7,362 participants in 2014-15, the most recent year for which data are available, the LSP was the tenth largest means-tested program in the country, in terms of the percentage of all school-aged children in the state served. In this regard, an analysis of the LSP offers useful insight into similar programs across the nation. 
Table 1.

Programmatic Details of Private School Choice Programs in the U.S., 2014-15

\begin{tabular}{|c|c|c|c|c|}
\hline State & Program & Enacted & Income-Limit if Program is Means Tested & Enrollment \\
\hline \multicolumn{5}{|c|}{ Tax Credit Scholarship Programs } \\
\hline Alabama & $\begin{array}{l}\text { Tax Credits for Contributions to } \\
\text { Scholarship Granting Organizations }\end{array}$ & 2013 & $\begin{array}{l}\text { Family income cannot exceed } 150 \% \text { of median } \\
\text { household income in Alabama }(\$ 60,734 \text { in } 2012)\end{array}$ & 2,851 \\
\hline Arizona & $\begin{array}{l}\text { Individual School Tuition Organization } \\
\text { Tax Credit }\end{array}$ & 1997 & Not Means Tested & 40,918 \\
\hline Arizona & $\begin{array}{l}\text { Corporate School Tuition Organization } \\
\text { Tax Credit }\end{array}$ & 2006 & $\begin{array}{l}\text { Family income cannot exceed } 185 \% \text { of the federal } \\
\text { free or reduced-price lunch level }(\$ 81,628 \text { for a } \\
\text { family of four in 2014) }\end{array}$ & 12,955 \\
\hline Arizona & Lexie's Law & 2009 & Not Means Tested & 345 \\
\hline Florida & Florida Tax Credit Scholarship & 2001 & $\begin{array}{l}\text { Family income cannot exceed } 185 \% \text { of the federal } \\
\text { poverty level }(\$ 44,123 \text { for a family of four in } 2014)\end{array}$ & 69,671 \\
\hline Georgia & $\begin{array}{l}\text { Georgia Scholarship Tax Credit } \\
\text { Program }\end{array}$ & 2008 & Not Means Tested & 13,268 \\
\hline Indiana & $\begin{array}{l}\text { Corporate and Individual Scholarship } \\
\text { Tax Credit Program }\end{array}$ & 2009 & $\begin{array}{l}\text { Family income cannot exceed } 200 \% \text { of the federal } \\
\text { free or reduced-price lunch level }(\$ 88,246 \text { for a } \\
\text { family of four in 2014) }\end{array}$ & 11,067 \\
\hline Iowa & $\begin{array}{l}\text { Individual and Corporate School Tuition } \\
\text { Organization Tax Credit }\end{array}$ & 2006 & $\begin{array}{l}\text { Family income cannot exceed } 300 \% \text { of the federal } \\
\text { poverty level }(\$ 71,550 \text { for a family of four in } 2014)\end{array}$ & 10,254 \\
\hline Kansas & $\begin{array}{l}\text { Tax Credit for Low Income Students } \\
\text { Scholarship Program }\end{array}$ & 2014 & $\begin{array}{l}\text { Family income cannot exceed } 100 \% \text { of the federal } \\
\text { poverty level }(\$ 23,850 \text { for a family of four in } 2014)\end{array}$ & $\mathrm{n} / \mathrm{a}$ \\
\hline Louisiana & Tuition Donation Rebate Program & 2012 & $\begin{array}{l}\text { Family income cannot exceed } 250 \% \text { of the federal } \\
\text { poverty level }(\$ 59,625 \text { for a family of four in } 2014)\end{array}$ & 53 \\
\hline $\begin{array}{l}\text { New } \\
\text { Hampshire }\end{array}$ & Education Tax Credit Program & 2012 & $\begin{array}{l}\text { Family income cannot exceed } 300 \% \text { of the federal } \\
\text { poverty level }(\$ 71,550 \text { for a family of four in } 2014)\end{array}$ & 40 \\
\hline Nevada & $\begin{array}{l}\text { Nevada Educational Choice Scholarship } \\
\text { Program }\end{array}$ & 2015 & $\begin{array}{l}\text { Family income cannot exceed } 300 \% \text { of the federal } \\
\text { poverty level }(\$ 71,550 \text { for a family of four in } 2014)\end{array}$ & $\mathrm{n} / \mathrm{a}$ \\
\hline Oklahoma & $\begin{array}{l}\text { Equal Opportunity Education } \\
\text { Scholarships }\end{array}$ & 2011 & $\begin{array}{l}\text { Family income cannot exceed } 300 \% \text { of the federal } \\
\text { free or reduced-price lunch level }(\$ 132,369 \text { for a } \\
\text { family of four in 2014) }\end{array}$ & 709 \\
\hline
\end{tabular}









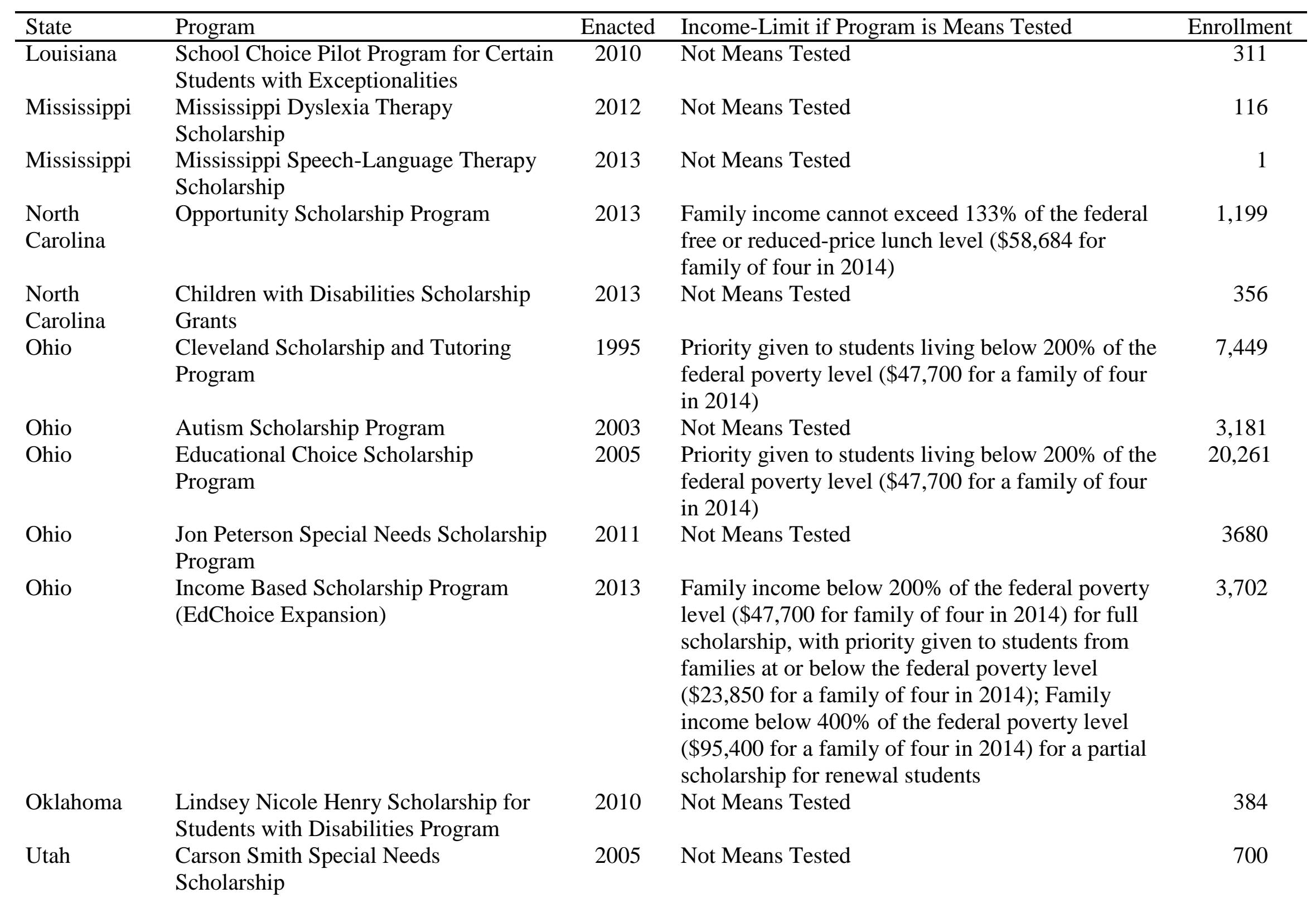




\begin{tabular}{|c|c|c|c|c|}
\hline State & Program & Enacted & Income-Limit if Program is Means Tested & Enrollment \\
\hline $\begin{array}{l}\text { Washington } \\
\text { D.C. }\end{array}$ & D.C. Opportunity Scholarship Program & 2004 & $\begin{array}{l}\text { Family income cannot exceed the federal free or } \\
\text { reduced-price lunch level }(\$ 44,123 \text { for a family of } \\
\text { four in 2014); } 300 \% \text { for renewal students }(\$ 71,550 \\
\text { for a family of four in 2014) }\end{array}$ & 1,442 \\
\hline Wisconsin & Milwaukee Parental Choice Program & 1990 & $\begin{array}{l}\text { Family income cannot exceed } 300 \% \text { of the federal } \\
\text { poverty level ( } \$ 71,550 \text { for a family of four in } \\
2014) \text {, with an additional } \$ 7,000 \text { allowed for } \\
\text { households with married parents }\end{array}$ & 26,930 \\
\hline Wisconsin & Wisconsin Parental Choice Program & 2013 & $\begin{array}{l}\text { Family income cannot exceed } 185 \% \text { of the federal } \\
\text { poverty level ( } \$ 44,123 \text { for a family of four in } \\
2014) \text {, with an additional } \$ 7,000 \text { allowed for } \\
\text { households with married parents }\end{array}$ & 1,007 \\
\hline Arizona & $\begin{array}{l}\text { Arizona Empowerment Scholarship } \\
\text { Accounts Program }\end{array}$ & 2011 & Not Means Tested & 1,311 \\
\hline Florida & Personal Learning Scholarship Accounts & 2014 & Not Means Tested & 1,294 \\
\hline Mississippi & $\begin{array}{l}\text { Equal Opportunity for Students with } \\
\text { Special Needs Program }\end{array}$ & 2015 & Not Means Tested & $\mathrm{n} / \mathrm{a}$ \\
\hline Tennessee & Individualized Education Program & 2015 & Not Means Tested & $\mathrm{n} / \mathrm{a}$ \\
\hline Nevada & $\begin{array}{l}\text { Nevada Education Savings Account } \\
\text { Program }\end{array}$ & 2015 & Not Means Tested & $\mathrm{n} / \mathrm{a}$ \\
\hline Subtotal & & & & 2,605 \\
\hline TOTAL & & & & 353,739 \\
\hline
\end{tabular}

Note: n/a means not applicable. This is because enrollment and expenditure statistics are not yet available for programs enacted in 2015. Sources: Frendeway, Sawatka, Marcavage, Carney, Martinez, \& Dauphin (2015); Annual Estimates of the Resident Population for Selected Age Groups by Sex for the United States, States, Counties, and Puerto Rico Commonwealth and Municipios: 2014 , U.S. Census Bureau, Population Division, June 2015. 


\section{Theoretical Framework}

The theory of reform behind market-based school choice programs is that expanded choice and competition will directly benefit participants by allowing them to seek out an effective school that best fits their needs and interests as well as exerting competitive pressure on traditional public schools to improve (Chubb \& Moe, 1990; Friedman, 1962), resulting in "a rising tide" of school improvement (Hoxby, 2001). In order for this theory to hold, a set of core assumptions must be upheld.

First, for an education marketplace to function as theorized, families must have valid and reliable information about their school options so that they select a high quality school that will be a good fit for their child's needs (Schneider, Teske, \& Marschall, 2000; Schneider, Teske, Marschall, \& Roch, 1998; Van Dunk \& Dickman, 2002). Second, the private and public school providers must be able to identify specific characteristics of high-performing schools so that they can judge which specific responses to competition will result in increased school quality. Bagley (2006) identifies five categories of operational responses by which schools might potentially respond to competition. This includes substantive changes to curriculum or facilities, in addition to structural changes to school governance. Given this variety of ways in which schools could potentially respond to competition, it is particularly important that school leaders are informed about factors related to school success so that they can learn from their competitors. Third, school leaders must be able to access those resources associated with their competitors' success. For example, families' choices may be constrained if funding is not provided for transportation to schools of choice (Ryan \& Heise, 2002). Similarly, some school leaders may face legal, political, or economic constraints that prevent them from replacing ineffective teachers with 
higher-quality ones (Anzia \& Moe, 2013; Cohen-Vogel \& Osborne-Lampkin, 2007; Egalite, Jensen, Stewart, \& Wolf, 2014).

Given these potential obstacles, and other scenarios by which market failure might occur, some have questioned if market-based school reforms could have unanticipated consequences, such as diminished resources, racial and economic segregation, and suboptimal academic experiences for the students who are left behind in public schools (Altonji, Huang, \& Taber, 2015; Brunner, Imazeki, \& Ross, 2010; Lankford \& Wyckoff, 2001). Further, national and state media outlets regularly run opinion columns in which prominent politicians, teachers' union leaders, and activists accuse private school vouchers of siphoning funds from public schools, arguing that private school choice programs remove financial resources from those public schools that are most in need of revenue in order to improve (McCall, 2014; Rich, 2014; Schrier, 2014; Weingarten, 2013).

In light of these factors, there are three primary responses we might hypothesize would result from injecting competitive pressure into K-12 public schooling in Louisiana. First, by granting students the financial resources to exit a dissatisfactory public school, vouchers might provide those public schools with a financial incentive to improve their performance. School leaders might work harder to encourage innovation, add or improve school programs, and organize staffing and curricula in a manner that is maximally responsive to student needs. Similarly, teachers and other staff members might exert more effort to tutor students or provide additional assistance where necessary. If this is the case, we might observe a general rise in test scores in those schools experiencing the strongest competitive pressures.

Alternatively, competition from a private school choice program might negatively influence teachers' job satisfaction, relations between school staff and parents, and teachers' 
quality of life (Ladd \& Fiske, 2003). Further, such competition might force traditional public schools to offer an overly diverse and thematically incoherent set of courses to appeal to a broad set of student interests (Fiske \& Ladd, 2000), which may come at the expense of deep instruction in core areas. Further, public schools' response to competition might involve limiting instructional and administrative staff or increasing class sizes. Responses to such changes might, in turn, result in a general lowering of morale and decline in school-wide performance. This could be exacerbated by compositional and resource changes if the highest-achieving and most motivated families were to exit the public schools en masse (Lubienski, Gulosino, \& Weitzel, 2009). If this were to happen, private school vouchers might rob the public schools of academic and social capital — the positive peer effects of high achieving classmates and the influence of motivated families who would push for overall school improvements - resulting in a downward spiral for public school performance. Thus, we might expect to see lower average scores and reduced parental involvement in those public schools that experienced the greatest competition (Epple \& Romano, 1998; Ladd, 2002; McMillan, 2000).

The third hypothesized response is none at all. If the threat from competition is trivial or schools simply respond with empty symbolic gestures (Hess, 2002; Sullivan, Campbell, \& Kisida, 2008), focusing on promotional activities (Lubienski, 2007) and marketing efforts (Jabbar, 2015; Loeb, Valant, \& Kasman, 2011) in lieu of improving academic programming, the impact of the choice program will not be detectable in students' academic outcomes. We might anticipate this scenario occurring if the private school voucher program is small in scale, underfunded, or politically unstable. An equally important explanation might be that schools are already maximizing performance given existing financial and physical resources as well as the human capital available to them. 


\section{Literature}

There is a wealth of empirical literature examining competition responses in traditional public schools occurring as the result of a private school choice program such as a tuition tax credit or voucher program. Of the 19 published studies of competitive effects from vouchers/ tax credit scholarships, all find neutral to positive results (Table 2). The majority of these studies have taken place in Florida (nine studies) and Milwaukee, Wisconsin (five studies). 
Table 2.

Empirical Studies of the Competitive Effects of Voucher/Tax Credit Scholarship Programs in the U.S.

\begin{tabular}{|c|c|c|c|c|c|}
\hline Study & $\begin{array}{c}\text { Publication } \\
\text { Year }\end{array}$ & Program Type & Competition Measure & $\begin{array}{l}\text { Summary } \\
\text { of Findings }\end{array}$ & $\begin{array}{l}\text { Published in a Peer- } \\
\text { Reviewed Journal? }\end{array}$ \\
\hline \multicolumn{6}{|l|}{ Florida (9) } \\
\hline Chakrabarti & 2013 & Voucher & Receipt of an 'F' grade & Positive & Yes \\
\hline Rouse et al. & 2013 & Voucher & Receipt of an 'F' grade & Positive & Yes \\
\hline Forster & 2008 & Voucher & Receipt of an 'F' grade & Positive & No \\
\hline Figlio and Rouse & 2006 & Voucher & Receipt of an 'F' grade & Positive & Yes \\
\hline West and Peterson & 2006 & Voucher & Receipt of an 'F' grade & Positive & Yes \\
\hline Greene and Winters & 2004 & Voucher & Receipt of an ' $F^{\prime}$ grade & Positive & Yes \\
\hline Greene & 2001 & Voucher & Receipt of an 'F' grade & Positive & No \\
\hline Greene and Winters & 2011 & $\begin{array}{l}\text { Disability } \\
\text { Voucher }\end{array}$ & $\begin{array}{l}\text { Density (voucher-accepting private } \\
\text { schools within } 5 \& 10 \text { miles) }\end{array}$ & Positive & Yes \\
\hline Figlio and Hart & 2014 & $\begin{array}{l}\text { Tax-credit } \\
\text { Scholarship }\end{array}$ & $\begin{array}{l}\text { Distance, Density, Diversity, } \\
\text { Concentration }\end{array}$ & Positive & Yes \\
\hline \multicolumn{6}{|l|}{ Milwaukee, WI (5) } \\
\hline Greene and Marsh & 2009 & Voucher & $\begin{array}{l}\text { Density (relevant private schools } \\
\text { within five different radii) }\end{array}$ & Positive & No \\
\hline Chakrabarti & 2008 & Voucher & $\begin{array}{l}\text { Share of poor children who would } \\
\text { qualify for vouchers }\end{array}$ & $\begin{array}{l}\text { Neutral to } \\
\text { Positive }\end{array}$ & Yes \\
\hline Carnoy et al. & 2007 & Voucher & $\begin{array}{l}\text { Share of poor children who would } \\
\text { qualify for vouchers; Density }\end{array}$ & Positive & No \\
\hline Hoxby & 2003 & Voucher & $\begin{array}{l}\text { Share of poor children who would } \\
\text { qualify for vouchers }\end{array}$ & Positive & No \\
\hline Greene and Forster & 2002 & Voucher & $\begin{array}{l}\text { Share of poor children who would } \\
\text { qualify for vouchers }\end{array}$ & $\begin{array}{l}\text { Neutral to } \\
\text { Positive }\end{array}$ & No \\
\hline \multicolumn{6}{|l|}{ Ohio (2) } \\
\hline Carr & 2011 & Voucher & $\begin{array}{l}\text { Public school is designated as } \\
\text { underperforming }\end{array}$ & Positive & Yes \\
\hline
\end{tabular}




\begin{tabular}{|c|c|c|c|c|c|}
\hline Forster & 2008 & Voucher & $\begin{array}{l}\text { Public school is designated as } \\
\text { chronically underperforming }\end{array}$ & $\begin{array}{l}\text { Neutral to } \\
\text { Positive }\end{array}$ & No \\
\hline \multicolumn{6}{|l|}{ San Antonio, TX (2) } \\
\hline $\begin{array}{l}\text { Gray, Merrifield, and } \\
\text { Adzima }\end{array}$ & 2014 & Voucher & $\begin{array}{l}\text { Compared Edgewood district to } \\
\text { other districts with no voucher } \\
\text { program }\end{array}$ & $\begin{array}{l}\text { Neutral to } \\
\text { Positive }\end{array}$ & Yes \\
\hline Greene and Forster & 2002 & Voucher & $\begin{array}{l}\text { Compared Edgewood district to } \\
\text { other districts with no voucher } \\
\text { program }\end{array}$ & Positive & No \\
\hline \multicolumn{6}{|c|}{ District of Columbia (1) } \\
\hline Greene and Winters & 2007 & Voucher & $\begin{array}{l}\text { Distance and Density (participating } \\
\text { private schools within } 1 \text { mile) }\end{array}$ & Neutral & Yes \\
\hline
\end{tabular}

Note: Publication information for each of the studies listed here is detailed in the references section. 
In the state of Florida, three programs have provided publicly-funded vouchers for private school tuition of public school students wishing to transfer to private schools. The first is the Florida Opportunity Scholarship Program, established as part of the reform program known as the A+ Plan, which offered school vouchers to students attending public schools that were designated as failing twice in a four-year period. This program ran from June 1999 until the Florida Supreme Court ruled it unconstitutional in January 2006. In total, there have been seven studies of the competitive effects of this program, all of which found positive competitive impacts on affected traditional public schools (Chakrabarti, 2013; Figlio \& Rouse, 2006; Forster, 2008a; Greene, 2001; Greene \& Winters, 2004; Rouse, Hannaway, Goldhaber, \& Figlio, 2013; West \& Peterson, 2006). The second program is the Florida Tax Credit Scholarship Program, established in 2001 and still in operation today, providing vouchers to students from low-income families. Figlio and Hart (2014) found that increases in competition as a result of this tax credit program were associated with improvements in student test scores across a variety of competition measures. The third Florida program is the McKay Scholarships for Students with Disabilities Program, established in 1999 and currently serving approximately 24,000 students. A 2008 study by Greene and Winters found that increased exposure to this voucher program is associated with substantial improvements in the test scores of students with disabilities that remain in the public school system.

Another highly studied private school choice program is the Milwaukee Parental Choice Program (MPCP). Established in 1999, the MPCP provides vouchers to low and middle-income families to attend private schools at state expense. All five published studies of the competitive effects of the MPCP have shown a mixture of neutral-to-positive results (Carnoy et al., 2007; Chakrabarti, 2008; Greene \& Forster, 2002; Greene \& Marsh, 2009; Hoxby, 2003;). Meanwhile, 
studies of competition effects from school voucher or tuition tax credit programs have also been conducted in Ohio (Carr, 2011; Forster, 2008b), Texas (Greene \& Forster, 2002; Gray, Merrifield, \& Adzima, 2014), and Washington D.C. (Greene \& Winters, 2007). Of these 19 total studies, only one - an analysis of a voucher program in Washington D.C. — showed no impacts across all subjects (Greene \& Winters, 2007).

A competitive effects analysis of the Louisiana Scholarship Program offers a number of distinct advantages over existing studies in this area. First, this study of the competitive effects of the LSP has a strong identification strategy that takes advantage of a panel dataset instead of running descriptive analyses of cross-sectional data. By applying a school fixed effects model, this study takes full advantage of the policy changes that resulted in the introduction of the voucher program, comparing pre-program trends to achievement outcomes after the introduction of the policy. Second, this study takes advantage of the geographic diversity of a major school voucher program affecting thousands of students across an entire state. This maximizes the variation in competition faced by public schools in this state and increases the external validity of the analysis. Thus, whereas much of the previous work in this area has examined impacts within a single city or region, our approach increases the opportunity for results to be relevant in other contexts. Third, although a number of panel studies already exist that examine the impact of a school voucher program across an entire state (i.e., Florida), these studies are unable to disentangle the accountability effects of the A-F school letter grading policy from the competitive effects of the voucher threat for consistently low-performing schools because both policies were implemented at the same time. In Louisiana, however, the A-F school letter grading policy predates the voucher program, making it possible to compare achievement trends before and after the introduction of the voucher program, without estimates being confounded by 
the accountability impact of a letter grading policy introduced concurrently, which has been shown to have significant impacts on student achievement (Bowen \& Trivitt, 2014).

Thus, this study represents the first panel data analysis of responses to private school competition conducted across an entire state and net of the stigma effect of an accountability policy.

\section{Data}

The data for this analysis come from a variety of sources. Student-level data on 2010-11 through 2012-13 public school test scores for students in grades three through eight in math and English Language Arts (ELA) come from a restricted-use data file provided by the Louisiana Department of Education. Data on 2010-11 school performance scores and letter grades are publicly available on the Louisiana Department of Education's website. Street addresses, latitude, and longitude for all public schools in Louisiana in 2010-11 were retrieved from the National Center for Education Statistics’ Public Elementary/Secondary School Universe Survey. Finally, private school street addresses and information on religious orientation were retrieved from the National Center for Education Statistics’ Private School Universe Survey (PSS), 2011-12.

\section{Sample Selection}

To generate the analysis sample, I start with the universe of public schools that appear in the NCES 2010-11 file. The first screen keeps only those public schools that could be successfully mapped using ArcGIS software (approximately 90 percent of schools). The second screen requires each school to have a minimum of three students taking the state test - the Louisiana Educational Assessment Program (LEAP) or integrated Louisiana Educational Assessment Program (iLEAP) — in grades three through eight, reducing the sample from 1,326 to 981 
schools. The third and fourth screens exclude charter schools, which already experience competition for enrollment and thus are not relevant for this study, and schools in New Orleans, where a pilot version of the LSP was already operating. This reduces the final sample to 781,733 students in 939 schools, a total of 676 of which received a "C," "D," or "F" grade at baseline, making their students voucher-eligible.

\section{Empirical Approach}

\section{Competition Measures}

I use a set of geocoded competition measures to capture variation in the level of private school competition experienced by public schools. These methods can be organized into four distinct categories: distance, density, diversity, and concentration.

A distance measure quantifies competition by measuring the distance between a public school and its nearest private school competitor. In a metropolitan area, it is not uncommon for this value to be under a mile. The underlying assumption for using distance as a measure of competitive pressure is that shorter distances equate to a higher level of school choices for students and thus increased competition for enrollees by public schools. This measure has been previously used in studies of the competition effect of the Florida Tax Credit Scholarship Program and the D.C. Opportunity Scholarship Program (Figlio \& Hart, 2014; Greene \& Winters, 2007). For each eligible public school, I calculate the crow's-flight distance—recorded in meters and converted to miles for analysis - to the nearest private school that was in existence before the announcement of the program. To ease interpretation, I multiply the distance variable by -1 so that a positive coefficient on the distance variable would represent the impact of closer competitors positively impacting student outcomes. 
A density measure quantifies the degree of competition faced by a school by counting the number of private competitors within a given radius. Such measures have been previously used in studies of competition effects of the Milwaukee Parental Choice Program, the Florida Tax Credit Scholarship Program, and Florida’s McKay Scholarship Program for Students with Disabilities (Carnoy et al., 2007; Figlio \& Hart, 2014; Greene \& Marsh, 2009; Greene \& Winters, 2008). I generate density counts within 5 and 10 mile radii.

A diversity measure counts the number of different types of local private schools that are close to a given public school. Using this method, competition is quantified by measuring the variety of schooling options available to students. Such a method has been previously used in a study of the Florida Tax Credit Scholarship Program (Figlio \& Hart, 2014). I define private school type by religious affiliation. Thus, a given public school might have a value of 6 on the density measure, but if all 6 schools were Roman Catholic, it would only score a 1 on the diversity measure.

The final competition measure uses a modified Herfindahl Index to capture market concentration. As described by Figlio and Hart (2014), this index is generated by summing the squared market shares held by each private school religious type within a given public school radius. Suppose, for instance, there are five private schools that fall within a ten mile radius of a given public school—four of these are Catholic schools and one is a Lutheran school. The market share for each school type is calculated as $\frac{\text { Count }_{r}}{\Sigma_{R} \text { Count }_{r}}$. Catholic school market share, therefore, is .80 (i.e., 4/5) and Lutheran market share is .20 (i.e., 1/5). The Herfindahl Index is the sum of the squares of the market shares held by each school type - in this case $(.80)^{\wedge} 2+$ $(.20)^{\wedge} 2=.68$. Lower values of the Herfindahl Index are indicative of increased competitive pressure, as a lower concentration of the share of private schools is in the hands of just one 
particular religious type. Thus, a Herfindahl Index score of 1 suggests a monopoly market environment, where just one religious type has control of all private competitors within that radius. Conversely, a Herfindahl Index score of 0 represents a school market that is well-served by a diverse set of private schools. To ease interpretation of results, I use 1- the Herfindahl Index so that a positive coefficient on this variable would mean increased competition is associated with higher student outcomes and a negative coefficient would mean increased competition is associated with lower student outcomes.

In general, for those public schools that are not matched to a single private school within each radius examined, it is appropriate to assign a zero as the competition measure for all of the competition measures described above except for the concentration measure, where a zero implies a perfectly competitive market. As such, those public schools not matched to a single private school must be dropped for those analyses relying upon the modified Herfindahl Index. In the results tables presented later in this article, the sample size is always smaller for those regressions measuring competition with the concentration index.

In order to avoid reverse causation bias, all four geocoded variables are generated using data from before either program was announced. It's also important to note that some of these measures are based on private school counts that weight all schools equally, regardless of school size. Such measures were deliberately chosen because one might expect that public school administrators are more likely to be aware of the existence of neighboring private schools than to be knowledgeable about the relative size of different competitors, such as knowing the number of enrollment slots that would be made available to students using a voucher. One potential criticism of these geocoded competition measures is that they suffer from endogeneity bias because the locations where public schools demonstrate poor performance might be attractive to 
choice schools with a mission to enroll underserved students. This is more likely to be a problem in studies of competitive effects of charter schools, however, given evidence of the endogeneity of charter school location (Glomm, Harris, \& Lo, 2005). In Louisiana, the private schools in question - mostly Catholic schools - existed for many years prior to the creation of the voucher program. Indeed, many of these schools were established in response to Catholic doctrine, which dictates that Catholic children should be educated in a Catholic school (Herbermann, 1912) and not in response to unsatisfactory public school performance.

Table 3 summarizes the four competition measures across both the five and ten mile radii. The average public school is 6.39 miles from a private competitor, with a standard deviation of just over eight miles. Within a five-mile radius, public schools in Louisiana typically have five private competitors. On average, approximately two religious denominational types are represented and the mean value for the Herfindahl Index is .56. The mean values for this set of variables are predictably larger within a ten-mile radius - the average school has 11 private competitors and approximately three religious denominational types are represented. The modified Herfindahl Index, meanwhile, has an average value of .50. 
Table 3.

Descriptive Statistics of Competition Measures

\begin{tabular}{lrrrr}
\hline & Mean & SD & Min & Max \\
\hline Distance & 6.39 & 8.23 & .04 & 49.85 \\
5 Mile Radius & & & & \\
$\quad$ Density & 5.07 & 9.10 & 0 & 59 \\
$\quad$ Diversity & 1.93 & 2.26 & 0 & 8 \\
$\quad$ Concentration & .56 & .30 & .12 & 1 \\
10 Mile Radius & & & & 100 \\
$\quad$ Density & 11.46 & 19.73 & 0 & 9 \\
Diversity & 2.86 & 2.58 & 0 & 1 \\
$\quad$ Concentration & .50 & .28 & 0 & \\
\hline
\end{tabular}

Note: Authors' calculations. Distance is the number of miles to nearest private school competitor; Density is the number of local private schools falling within a given radius; Diversity is the number of religious denominational types represented; Concentration is calculated as a modified Herfindahl Index

Source: Public school addresses from the National Center for Education Statistics, Common Core of Data (CCD), "Public Elementary/Secondary School Universe Survey", 2010-11. Private school addresses from the Private School Universe Survey, 2011-12 


\section{Model}

A school fixed effects model is employed to estimate the effect of private school competition on public school performance, building upon the model estimated by Figlio and Hart (2014). The model takes the form

$$
\mathrm{Y}_{i s t}=\alpha_{s}+\beta_{1} C_{s} * P_{t} * \mathrm{CDF}_{t}+\beta_{2} P_{t} * C_{s}+\beta_{3} P_{t} * C D F_{t}+\gamma \mathrm{X}_{i t}+\mu S_{s t}+\delta \mathrm{T}_{t}+\epsilon_{i s t}
$$

where $\mathrm{Y}_{i s t}$ is the standardized math or reading score for student $i$ in school $s$ in year $t$; $\alpha_{\mathrm{s}}$ is a school fixed effect; $\mathrm{C}_{\mathrm{s}}$ is the measure of pre-policy competitive pressure facing school $s ; P_{t}$ is an indicator variable identifying the post-policy year; $\mathrm{CDF}_{\mathrm{t}}$ is an indicator variable identifying those schools that became voucher eligible because they received a "C," "D," or "F" grade from the state in 2011; $X_{i t}$ is a vector of student demographic control variables including gender, race, special education status, an indicator for limited English proficiency (LEP), and eligibility for free/reduced lunch for student $i$ in year $t ; S_{s t}$ is a vector of time-varying school characteristics (shares of students of each race and gender, the share eligible for free/reduced lunch, and the shares classified as LEP or special education); and $T_{t}$ is a set of dummy variables indicating year. The $\beta_{1}$ coefficient on the three-way-interaction of competition measures, post-policy year indicator, and a school's "C," "D," or "F" grade is the parameter of interest. Standard errors are clustered at the school level.

I start by running this model excluding all charter schools and all schools in New Orleans. I then repeat the analysis, keeping these schools in the analysis sample to see if their inclusion results in significant changes to the findings. The primary concern with including charter schools is that such schools are not experiencing a competitive "shock" in the same way that traditional public schools are, given that the theory of action behind charter school 
authorization in general is to stimulate innovation and improvement in student achievement by setting up autonomous but highly accountable schools that must attract students in order to stay open. The concern with including schools in New Orleans, meanwhile, is that the school system in that city experienced a dramatic overhaul in the wake of Hurricane Katrina that resulted in the creation of a unique, reform-driven educational environment built on accountability, choice, and competition (Jabbar, 2015). "D" and "F" schools in New Orleans are under intense threat of closure, which is likely to be correlated with the outcome variable. Interacting the four competition measures with an indicator for "C," "D," or "F" graded schools is one step towards addressing this potential confound but doesn't entirely address the problem because there are more private schools in New Orleans than in other parts of the state. Thus, the distance, density, diversity, and concentration measures are correlated with schools being in New Orleans, a city that has experienced significant growth in test scores in recent years (Harris, 2015). The final element of the three-way interaction goes a long way towards addressing this confounding factor, however. By comparing schools' performance before and after the LSP policy change, the model isolates any changes in achievement that are directly related to the policy implementation. To test this important assumption, I run a placebo test that changes the "post policy" year to one year earlier in the data, when we would not expect to find any significant effects.

A second identification concern arises from Louisiana's application for a waiver from the Elementary and Secondary Education Act, which won approval from the U.S. Department of Education in May 2012. This waiver granted the state flexibility from some of No Child Left Behind (NCLB)'s accountability sanctions. In particular, the waiver allowed Louisiana to give districts and schools increased flexibility in how to spend federal education funding of approximately $\$ 375$ million per year. In return, the state of Louisiana agreed to institute a 
rigorous accountability system and adopt the Common Core State Standards and aligned assessments. There is little empirical evidence available yet on the productivity impact of NCLB waivers to draw upon but it is unlikely to be a major confounding concern for this analysis because both sets of schools being compared in this study ("A"- and "B"- graded schools, compared to "C," "D," and "F"- graded schools) would have been subject to the same accountability pressure associated with Louisiana's NCLB waiver.

\section{Results}

The estimates reported in Table 4 represent the $\beta_{1}$ coefficient on the three-way interaction between competition measure, post-policy year, and "C," "D," or "F" school grade. The top panel displays the main results across all eligible public schools in Louisiana, "C" through "F." Within a ten-mile radius, competition is shown to have a statistically significant positive impact in math for two of the four measures used-density and diversity. As the radius narrows to five miles, I continue to observe statistically significant positive impacts in math with the density and diversity measures. There are no statistically significant impacts on ELA performance. 
Table 4.

School Fixed Effects Regression Estimates of the Impact of LSP Competition on Traditional Public School Achievement Across the State of Louisiana, First Year Impacts.

\begin{tabular}{|c|c|c|c|c|c|c|c|c|}
\hline & \multicolumn{4}{|c|}{10 Mile Radius } & \multicolumn{4}{|c|}{5 Mile Radius } \\
\hline & $\begin{array}{l}\text { Distance } \\
(\mathrm{r})\end{array}$ & Density & Diversity & $\begin{array}{c}\text { Concentratio } \\
n(r)\end{array}$ & $\begin{array}{l}\text { Distance } \\
\text { (r) }\end{array}$ & Density & Diversity & $\begin{array}{c}\text { Concentration } \\
\text { (r) }\end{array}$ \\
\hline & (1) & (2) & (3) & (4) & $(5)$ & (6) & (7) & $(8)$ \\
\hline \multicolumn{9}{|l|}{ Main Results } \\
\hline ELA & $\begin{array}{l}-.10 \\
(.07)\end{array}$ & $\begin{array}{l}.02 \\
(.03)\end{array}$ & $\begin{array}{l}.12 \\
(.22)\end{array}$ & $\begin{array}{c}-.08 \\
(2.51)\end{array}$ & $\begin{array}{l}-.10 \\
(.07)\end{array}$ & $\begin{array}{l}.00 \\
(.06)\end{array}$ & $\begin{array}{c}.07 \\
(.31)\end{array}$ & $\begin{array}{c}-.21 \\
(1.92)\end{array}$ \\
\hline Observations & 781,703 & 781,703 & 781,703 & 639,533 & 781,703 & 781,703 & 781,703 & 532,363 \\
\hline Unique Schools & 939 & 939 & 939 & 721 & 939 & 939 & 939 & 587 \\
\hline Adj. R-Squared & .27 & .27 & .27 & .28 & .27 & .27 & .27 & .29 \\
\hline Math & $\begin{array}{l}.05 \\
(.10)\end{array}$ & $\begin{array}{l}.11^{* * * *} \\
(.04)\end{array}$ & $\begin{array}{l}.92 * * * \\
(.30)\end{array}$ & $\begin{array}{c}3.05 \\
(3.08)\end{array}$ & $\begin{array}{l}.05 \\
(.10)\end{array}$ & $\begin{array}{l}.23 * * * \\
(.08)\end{array}$ & $\begin{array}{c}1.18 * * * \\
(.41)\end{array}$ & $\begin{array}{c}3.96 \\
(3.45)\end{array}$ \\
\hline Observations & 781,733 & 781,733 & 781,733 & 639,562 & 781,733 & 781,733 & 781,733 & 532,386 \\
\hline $\begin{array}{l}\text { Unique } \\
\text { Schools }\end{array}$ & 939 & 939 & 939 & 721 & 939 & 939 & 939 & 587 \\
\hline Adj. R-Squared & .25 & .25 & .25 & .26 & .25 & .25 & .25 & .28 \\
\hline \multicolumn{9}{|l|}{ "C" Schools Only } \\
\hline ELA & $\begin{array}{l}-.15^{* *} \\
(.07)\end{array}$ & $\begin{array}{l}.00 \\
(.04)\end{array}$ & $\begin{array}{l}-.14 \\
(.23)\end{array}$ & $\begin{array}{l}-1.96 \\
(2.71)\end{array}$ & $\begin{array}{l}-.15^{* *} \\
(.07)\end{array}$ & $\begin{array}{l}-. .08 \\
(.07)\end{array}$ & $\begin{array}{l}-.39 \\
(.35)\end{array}$ & $\begin{array}{l}-1.48 \\
(2.02)\end{array}$ \\
\hline Observations & 499,695 & 499,695 & 499,695 & 398,588 & 499,695 & 499,695 & 499,695 & 316,119 \\
\hline Unique Schools & 560 & 560 & 560 & 411 & 560 & 560 & 560 & 312 \\
\hline Adj. R-Squared & .23 & .23 & .23 & .24 & .23 & .23 & .23 & .25 \\
\hline Math & $\begin{array}{c}.04 \\
(.10)\end{array}$ & $\begin{array}{l}.08 \\
(.05)\end{array}$ & $\begin{array}{l}.62^{*} \\
(.33)\end{array}$ & $\begin{array}{l}-1.45 \\
(3.45)\end{array}$ & $\begin{array}{l}.04 \\
(.10)\end{array}$ & $\begin{array}{l}.13 \\
(.10)\end{array}$ & $\begin{array}{l}.58 \\
(.48)\end{array}$ & $\begin{array}{c}2.46 \\
(4.00)\end{array}$ \\
\hline Observations & 499,719 & 499,719 & 499,719 & 398,609 & 499,719 & 499,719 & 499,719 & 316,136 \\
\hline
\end{tabular}




\begin{tabular}{|c|c|c|c|c|c|c|c|c|}
\hline Unique & 560 & 560 & 560 & 411 & 560 & 560 & 560 & 312 \\
\hline Adj. R-Squared & .21 & .21 & .21 & .22 & .21 & .21 & .21 & .24 \\
\hline \multicolumn{9}{|l|}{ "D" Schools Only } \\
\hline ELA & $\begin{array}{l}-.05 \\
(.10)\end{array}$ & $\begin{array}{c}.03 \\
(.03)\end{array}$ & $\begin{array}{c}.37 \\
(.27)\end{array}$ & $\begin{array}{l}1.79 \\
(2.87)\end{array}$ & $\begin{array}{l}-.05 \\
(.10)\end{array}$ & $\begin{array}{l}.03 \\
(.07)\end{array}$ & $\begin{array}{c}.41 \\
(.38)\end{array}$ & $\begin{array}{c}-.53 \\
(2.62)\end{array}$ \\
\hline Observations & 512,648 & 512,648 & 512,648 & 439,607 & 512,648 & 512,648 & 512,648 & 372,420 \\
\hline Unique Schools & 607 & 607 & 607 & 490 & 607 & 607 & 607 & 406 \\
\hline Adj. R-Squared & .30 & .30 & .30 & .30 & .30 & .30 & .30 & .31 \\
\hline Math & $\begin{array}{c}.01 \\
(.13)\end{array}$ & $\begin{array}{l}.12 * * * \\
(.04)\end{array}$ & $\begin{array}{l}1.11 * * * \\
(.35)\end{array}$ & $\begin{array}{c}6.67 * \\
(3.47)\end{array}$ & $\begin{array}{c}.01 \\
(.13)\end{array}$ & $\begin{array}{l}.26 * * * \\
(.09)\end{array}$ & $\begin{array}{c}1.46 * * * \\
(.48)\end{array}$ & $\begin{array}{c}2.51 \\
(3.76)\end{array}$ \\
\hline Observations & 512,664 & 512,664 & 512,664 & 439,624 & 512,664 & 512,664 & 512,664 & 372,433 \\
\hline $\begin{array}{l}\text { Unique } \\
\text { Schools }\end{array}$ & 607 & 607 & 607 & 490 & 607 & 607 & 607 & 406 \\
\hline Adj. R-Squared & .28 & .28 & .28 & .29 & .28 & .28 & .28 & .30 \\
\hline \multicolumn{9}{|l|}{ "F" Schools Only } \\
\hline ELA & $\begin{array}{c}.04 \\
(.36)\end{array}$ & $\begin{array}{l}-.15 \\
(.10)\end{array}$ & $\begin{array}{l}-.79 \\
(.81)\end{array}$ & $\begin{array}{l}-7.92 \\
(9.92)\end{array}$ & $\begin{array}{c}.04 \\
(.36)\end{array}$ & $\begin{array}{l}-.20 \\
(.22)\end{array}$ & $\begin{array}{l}-1.27 \\
(1.11)\end{array}$ & $\begin{array}{c}6.57 \\
(5.84)\end{array}$ \\
\hline Observations & 263,146 & 263,146 & 263,146 & 230,092 & 263,146 & 263,146 & 263,146 & 187,526 \\
\hline Unique Schools & 298 & 298 & 298 & 248 & 298 & 298 & 298 & 197 \\
\hline Adj. R-Squared & .29 & .29 & .29 & .30 & .29 & .29 & .29 & .33 \\
\hline Math & $\begin{array}{c}2.19 * * * \\
(.74)\end{array}$ & $\begin{array}{c}.08 \\
(.13)\end{array}$ & $\begin{array}{c}.80 \\
(1.02)\end{array}$ & $\begin{array}{l}-4.57 \\
(8.80)\end{array}$ & $\begin{array}{c}2.19 * * * \\
(.74)\end{array}$ & $\begin{array}{l}.26 \\
(.27)\end{array}$ & $\begin{array}{c}1.04 \\
(1.25)\end{array}$ & $\begin{array}{l}29.81 * * * \\
(9.67)\end{array}$ \\
\hline Observations & 263,160 & 263,160 & 263,160 & 230,105 & 263,160 & 263,160 & 263,160 & 187,537 \\
\hline $\begin{array}{l}\text { Unique } \\
\text { Schools }\end{array}$ & 298 & 298 & 298 & 248 & 298 & 298 & 298 & 197 \\
\hline Adj. R-Squared & .27 & .27 & .27 & .28 & .27 & .27 & .27 & .30 \\
\hline
\end{tabular}




\begin{tabular}{|c|c|c|c|c|c|c|c|c|}
\hline \multicolumn{9}{|l|}{ Placebo Test } \\
\hline ELA & $\begin{array}{l}.07 \\
(.07)\end{array}$ & $\begin{array}{l}-.04 \\
(.03)\end{array}$ & $\begin{array}{l}.18 \\
(.23)\end{array}$ & $\begin{array}{c}.63 \\
(2.44)\end{array}$ & $\begin{array}{l}.07 \\
(.07)\end{array}$ & $\begin{array}{l}.03 \\
(.05)\end{array}$ & $\begin{array}{l}-.23 \\
(.32)\end{array}$ & $\begin{array}{c}.19 \\
(2.22)\end{array}$ \\
\hline Observations & 781,703 & 781,703 & 781,703 & 639,533 & 781,703 & 781,703 & 781,703 & 532,363 \\
\hline Unique Schools & 939 & 939 & 939 & 721 & 939 & 939 & 939 & 587 \\
\hline Adj. R-Squared & .27 & .27 & .27 & .28 & .27 & .27 & .27 & .27 \\
\hline Math & $\begin{array}{l}-.01 \\
(.08)\end{array}$ & $\begin{array}{l}-.05 \\
(.03)\end{array}$ & $\begin{array}{l}-.49 \\
(.30)\end{array}$ & $\begin{array}{l}-3.11 \\
(3.17)\end{array}$ & $\begin{array}{l}-.01 \\
(.08)\end{array}$ & $\begin{array}{l}-.10 \\
(.07)\end{array}$ & $\begin{array}{l}-.65^{*} \\
(.39)\end{array}$ & $\begin{array}{l}-1.62 \\
(3.33)\end{array}$ \\
\hline Observations & 781,733 & 781,733 & 781,733 & 639,562 & 781,733 & 781,733 & 781,733 & 532,386 \\
\hline $\begin{array}{l}\text { Unique } \\
\text { Schools }\end{array}$ & 939 & 939 & 939 & 721 & 939 & 939 & 939 & 587 \\
\hline Adj. R-Squared & .25 & .25 & .25 & .26 & .25 & .25 & .25 & .27 \\
\hline
\end{tabular}

Note: The dependent variable is the standardized math or English Language Arts score; Standard errors clustered by school in parentheses; Variables followed by (r) are reverse coded to ease interpretation; Each cell represents the coefficient estimate on the interaction between the competition measure, being a "C," "D," or "F" school in Oct 2011, and a post-policy indicator. Coefficients are multiplied by 100 for interpretability. Controls at the student level include indicators for gender, race, subsidized lunch eligibility, limited English proficiency (LEP), and special education. Controls at the school level include percent male, percent of each race, percent of student body eligible for subsidized lunch, percent LEP, and percent special education. Models also include school and year fixed effects; New Orleans' schools and charter schools are excluded from this sample; *** $\mathrm{p}<0.01, * * \mathrm{p}<0.05, * \mathrm{p}<0.10$ 
Specifically, each additional private school located within a 10-mile radius of a given public school is associated with a $.0011 \mathrm{SD}$ increase in math performance. ${ }^{1}$ As we might expect, the competitive effect is stronger as the radius narrows. Within a 5-mile radius, each additional private school is associated with a $.0023 \mathrm{SD}$ increase in math performance. In terms of diversity, the addition of one private school religious type within a 10-mile radius is associated with a $.0092 \mathrm{SD}$ increase in math performance. Again, that effect size grows larger when we narrow the radius within which we measure competition. Within a 5-mile radius, the addition of one private school religious type is associated with a $.0118 \mathrm{SD}$ increase in math performance. Overall, this evidence indicates a one-unit increase in competition is associated with a null to $.0118 \mathrm{SD}$ increase in math performance. Although these estimated effects appear modest in magnitude, they are consistent with the prior literature on the competitive effects of private school choice programs, such as the analysis of the Florida Tax Credit Scholarship Program by Figlio and Hart (2014), which found increases of .0008 SD for each additional type of nearby private school and $.0015 \mathrm{SD}$ for every mile the nearest private school moves closer.

In order to parse out the treatment effect to better understand which, if any, public schools may be affected by the LSP, the next three panels compare only a segment of all voucher-eligible public schools at a time. The second panel of Table 4 compares " $\mathrm{A}$ " and "B" graded public schools to just "C" schools, which produced around $18 \%$ of the total voucher winners (not including students coming from charter schools or schools within New Orleans, which are excluded from this analysis). Given the small number of voucher users coming from "C"- graded public schools, I do not expect to find strong evidence of a competitive response by this group of schools. Indeed, I find mostly null impacts on math scores, with the exception of a

\footnotetext{
${ }^{1}$ Coefficients in the table are multiplied by100 to assist with the interpretation of very small effects.
} 
marginally significant $.0062 \mathrm{SD}$ increase associated with the diversity measure in a 10 -mile radius. In the models that use students' ELA achievement as the dependent variable, the coefficients on three of the four competition measures reveal null impacts on student outcomes in both radii examined. Interestingly, however, student ELA achievement is negatively associated with competition using the distance measure, with an effect size of -.0015 SD.

The third panel reduces the treatment group to just "D" schools. Given that approximately three-quarters of voucher-winners in our sample came from a "D" -graded public school, this is the group for which I most strongly expect to find a competitive response to the LSP, if there was one. Indeed, the math results observed for this group of schools are statistically significant and positive for three out of four measures - density, diversity, and concentration. The ELA results, meanwhile, are consistently insignificant. In sum, when I examine the LSP's impact on just "D" schools, the competitive effect on math outcomes ranges from null effects to .0667 of a standard deviation.

Looking at the treatment impact on just "F" schools, I observe statistically significant, positive effects on students' math achievement using two of the four competition measures and exclusively null effects in ELA. Even though only $8 \%$ of voucher winners came from "F"-graded public schools, there were approximately five applicants and two winners per school. ${ }^{2}$ It is perhaps unsurprising, therefore, that I find the largest statistically significant impacts for this group of schools. Every mile the nearest private school moves closer, public school student math score performance in the period after the enactment of the LSP policy increases by .0219 SD. The magnitude of this positive and statistically significant effect size is consistent in both models - the one relying on a 10- mile radius and the one relying on a 5-mile radius. The largest

\footnotetext{
${ }^{2}$ By contrast, in the overall sample there was an average of 3 applicants and a single winner per school
} 
result, by far, is associated with the concentration measure of competition. A one-unit increase in the Herfindahl Index in a five-mile radius is associated with a 2981 SD increase in student math achievement. Overall, the results for " $D$ " and "F" schools in Louisiana suggest that those schools in the sample that experienced the greatest loss of students to the LSP responded with a modest yet positive increase in students' math outcomes.

The final panel of Table 4 displays the results of a placebo test I conduct that changes the “post-policy year" indicator from 2013 to 2011, before the LSP expansion was actually enacted. I expect to find null results associated with the competition measures in this model and with one exception that is the case. The only statistically significant coefficient reported from the sixteen regressions represented in the final panel of Table 4 is a negative coefficient of -.0065 SD associated with the diversity measure in a five-mile radius which is marginally significant at $\mathrm{p}<$ .10. Overall, given that none of the coefficients in the final panel are statistically significant at conventional levels $(\mathrm{p}<.05)$, this builds confidence in the validity of the empirical model employed.

\section{Follow Up Analyses}

There are two important follow-up analyses to consider. First, I add charter schools to the analysis sample to increase the statistical power of the model by increasing the sample size and thus yielding more precise estimates of the impact of competition on math and ELA outcomes. Second, I add both charter schools and schools in New Orleans to the analysis sample (Table 5). 


\section{Table 5.}

School Fixed Effects Regression Estimates of the Impact of LSP Competition on Public School Achievement, Follow Up Analyses

\begin{tabular}{|c|c|c|c|c|c|c|c|c|}
\hline & \multicolumn{4}{|c|}{10 Mile Radius } & \multicolumn{4}{|c|}{5 Mile Radius } \\
\hline & $\begin{array}{l}\text { Distance } \\
(\mathrm{r})\end{array}$ & Density & Diversity & $\begin{array}{l}\text { Concentration } \\
\text { (r) }\end{array}$ & $\begin{array}{l}\text { Distance } \\
(\mathrm{r})\end{array}$ & Density & Diversity & $\begin{array}{l}\text { Concentration } \\
\text { (r) }\end{array}$ \\
\hline & (1) & (2) & (3) & (4) & (5) & (6) & (7) & (8) \\
\hline \multicolumn{9}{|c|}{ Including Charter Schools } \\
\hline ELA & $\begin{array}{l}-.09 \\
(.07)\end{array}$ & $\begin{array}{l}.02 \\
(.03)\end{array}$ & $\begin{array}{l}.15 \\
(.22)\end{array}$ & $\begin{array}{c}-.32 \\
(2.51)\end{array}$ & $\begin{array}{l}-. .09 \\
(.07)\end{array}$ & $\begin{array}{l}-.01 \\
(.06)\end{array}$ & $\begin{array}{l}.07 \\
(.31)\end{array}$ & $\begin{array}{c}-.30 \\
(1.91)\end{array}$ \\
\hline Observations & 789,846 & 789,846 & 789,846 & 645,082 & 789,846 & 789,846 & 789,846 & 537,912 \\
\hline $\begin{array}{l}\text { Unique } \\
\text { Schools }\end{array}$ & 981 & 951 & 951 & 730 & 951 & 951 & 951 & 596 \\
\hline $\begin{array}{l}\text { Adj. R- } \\
\text { Squared }\end{array}$ & .27 & .27 & .27 & .28 & .27 & .27 & .27 & .29 \\
\hline Math & $\begin{array}{c}.05 \\
(.10)\end{array}$ & $\begin{array}{l}.08 * * \\
(.04)\end{array}$ & $\begin{array}{l}.88^{* * *} \\
(.30)\end{array}$ & $\begin{array}{c}2.71 \\
(3.07)\end{array}$ & $\begin{array}{c}.05 \\
(.10)\end{array}$ & $\begin{array}{l}.18^{* *} \\
(.09)\end{array}$ & $\begin{array}{c}1.09 * * * \\
(.41)\end{array}$ & $\begin{array}{c}3.83 \\
(3.45)\end{array}$ \\
\hline Observations & 789,877 & 789,877 & 789,877 & 645,112 & 789,877 & 789,877 & 789,877 & 537,936 \\
\hline $\begin{array}{l}\text { Unique } \\
\text { Schools }\end{array}$ & 951 & 951 & 951 & 730 & 951 & 951 & 951 & 596 \\
\hline $\begin{array}{l}\text { Adj. R- } \\
\text { Squared }\end{array}$ & .25 & .25 & .25 & .26 & .25 & .25 & .25 & .27 \\
\hline \multicolumn{9}{|c|}{ Including Charter Schools and New Orleans } \\
\hline ELA & $\begin{array}{l}-.06 \\
(.07)\end{array}$ & $\begin{array}{l}.05^{* *} \\
(.03)\end{array}$ & $\begin{array}{l}.32 \\
(.21)\end{array}$ & $\begin{array}{c}.18 \\
(2.51)\end{array}$ & $\begin{array}{l}-.06 \\
(.07)\end{array}$ & $\begin{array}{l}.08 \\
(.05)\end{array}$ & $\begin{array}{c}.33 \\
(.31)\end{array}$ & $\begin{array}{c}.24 \\
(1.90)\end{array}$ \\
\hline Observations & 816,442 & 816,442 & 816,442 & 671,678 & 816,442 & 816,442 & 816,442 & 564,508 \\
\hline $\begin{array}{l}\text { Unique } \\
\text { Schools }\end{array}$ & 981 & 981 & 981 & 760 & 981 & 981 & 981 & 626 \\
\hline
\end{tabular}




\begin{tabular}{|c|c|c|c|c|c|c|c|c|}
\hline $\begin{array}{l}\text { Adj. R- } \\
\text { Squared }\end{array}$ & .27 & .27 & .27 & .28 & .27 & .27 & .27 & .29 \\
\hline Math & $\begin{array}{c}.09 \\
(.10)\end{array}$ & $\begin{array}{l}.11 * * * \\
(.03)\end{array}$ & $\begin{array}{c}1.02 * * * \\
(.29)\end{array}$ & $\begin{array}{c}3.46 \\
(3.07)\end{array}$ & $\begin{array}{c}.09 \\
(.10)\end{array}$ & $\begin{array}{l}.21 * * * \\
(.07)\end{array}$ & $\begin{array}{c}1.35^{* * * *} \\
(.41)\end{array}$ & $\begin{array}{c}4.47 \\
(3.41)\end{array}$ \\
\hline Observations & 816,470 & 816,470 & 816,470 & 671,705 & 816,470 & 816,470 & 816,470 & 564,529 \\
\hline $\begin{array}{l}\text { Unique } \\
\text { Schools }\end{array}$ & 981 & 981 & 981 & 760 & 981 & 981 & 981 & 626 \\
\hline $\begin{array}{l}\text { Adj. R- } \\
\text { Squared }\end{array}$ & .25 & .25 & .25 & .26 & .25 & .25 & .25 & .28 \\
\hline
\end{tabular}

Note: The dependent variable is the standardized math or English Language Arts score; Standard errors clustered by school in parentheses; Variables followed by (r) are reverse coded to ease interpretation; Each cell represents the coefficient estimate on the interaction between the competition measure, being a "C," "D," or "F" school in Oct 2011, and a post-policy indicator. Coefficients are multiplied by 100 for interpretability. Controls at the student level include indicators for gender, race, subsidized lunch eligibility, limited English proficiency (LEP), and special education. Controls at the school level include percent male, percent of each race, percent of student body eligible for subsidized lunch, percent LEP, and percent special education. Models also include school and year fixed effects; New Orleans' schools are excluded from this sample; $* * * p<0.01, * * p<0.05, * \mathrm{p}<0.1$ 
Even though charter schools already operate in a competitive marketplace for students, it is possible that the expansion of the voucher program served as a mild competitive shock for this group of schools by introducing a new set of private school competitors that would previously have been financially unattainable for the majority of students they serve. The results presented in the top panel of Table 5 confirm this intuition. The coefficients associated with the density and diversity measures of competition remain statistically significant, but are smaller in magnitude than those reported in the models which focused on changes in traditional public school achievement only. Specifically, each additional private school located within a 10-mile radius of a given public or charter school is associated with a $.0008 \mathrm{SD}$ increase in math performance of students in both traditional public and charter schools. The corresponding statistic in a five-mile radius is a $.0018 \mathrm{SD}$ increase. In terms of diversity, the addition of one private school religious type within a 10-mile radius is associated with a $.0088 \mathrm{SD}$ increase in math performance. As before, that effect size grows larger when we narrow the radius within which we measure competition. Within a 5-mile radius, the addition of one private school religious type is associated with a $.0109 \mathrm{SD}$ increase in the math performance of students in both traditional public and charter schools.

While all analyses thus far exclude New Orleans because of the presence of a pilot version of the LSP in that city prior to the program's statewide expansion, it is worth examining if the competitive effects of neighboring private schools became more salient in New Orleans with the expansion of the LSP. Because the majority (84\%) of public schools in New Orleans are charter schools and not traditional public schools (Arce-Trigatti, Harris, Jabbar, \& Lincove 2015), this requires two changes to the analysis sample. Thus, I repeat the statewide analysis described in (1), this time including all charter schools and all public schools (traditional and 
charter) in New Orleans for which I have data. The results are presented in the bottom panel of Table 5. For the first time, there is a positive and statistically significant effect on students' ELA achievement. Specifically, each additional private school located within a 10-mile radius of a given public or charter school is associated with a .0005 SD increase in ELA performance. Meanwhile, the coefficients associated with the impact of competition density and diversity on math performance remain statistically significant and similar in magnitude to those reported in the primary analysis, which excluded New Orleans and charter schools. Specifically, each additional private school located within a 10-mile (5-mile) radius of a given public or charter school is associated with a $.0011 \mathrm{SD}(.0021 \mathrm{SD})$ increase in math performance. In terms of diversity, the addition of one private school religious type within a 10-mile (5-mile) radius is associated with a .0102 SD (.0135 SD) increase in math performance.

\section{Secondary Empirical Approach}

Given that the voucher program design limited participation to students in public schools that received a "C," "D," or "F" grade at baseline, it is possible to run a secondary analysis to confirm the findings reported above. I employ an alternative identification strategy with stronger internal validity — a regression discontinuity $(\mathrm{RD})$ design — to see if the main results can be replicated. If the estimates obtained from the RD analysis are largely consistent with the measured estimates for "C" schools in the primary analysis, I can be more confident in the validity of the primary results.

The LSP is an ideal situation to apply an RD analysis because school exposure to competition from the LSP depends upon ratings from the Louisiana letter grade system for public schools, part of the school and district accountability system. Letter grades are determined by a continuous measure known as the school performance score, which is an index of proficiency 
status in ELA, math, science, and social studies, and expected normative student longitudinal growth. Intervals along the school performance score continuum equate to a given letter grade. Low-income students wishing to participate in the LSP must have attended a public school that received a letter grade of "C", "D", or "F" for the most recent school year in order for students to qualify for voucher eligibility. It is reasonable to expect that schools that scored at the lowest threshold for receiving a "B" do not differ in substantial ways from those schools that scored at the highest threshold for receiving a "C," allowing for direct comparisons between schools in these two groups. The primary difference between these two groups of schools is that those schools that received a "C" grade or lower in October 2011 were directly exposed to vouchers for their low-income students. A subset of "high-C" schools, therefore, constitutes the treatment group for the RD competitive effects analysis of the LSP. It is important to note that, in contrast to the primary analysis, "high-C" schools in the RD are deemed to experience the threat of competition even if there are no private schools nearby. Meanwhile, the schools that received a low "B" grade had a school performance score that was close to the "C" schools, but they were not directly treated by the program because they were just above the cut-point. A subset of "lowB" schools therefore, constitutes the control group.

\section{RD Sample Selection}

Figure 1 demonstrates the screening process used to generate the RD analysis sample. Starting with the universe of students in the state's testing file in 2010-11, I merge this information with the state's school performance score file for 2010-11, generating an initial sample of 307,772 students. The first screen keeps those students who have taken the state test (the LEAP or iLEAP) as opposed to an alternative assessment such as those used by students with special educational needs, reducing the sample to 298,868 . The second screen excludes those students 
who won the LSP voucher lottery, reducing the sample to 297,766. This ensures that the sample is capturing those public school students who remained in the public school system. The third and fourth screens exclude charter schools, which already experience competition for enrollment and thus are not relevant for this study, and schools in New Orleans, where a pilot version of the LSP was already operating. ${ }^{3}$ This leaves 276,616 students, of which 64,952 attended a "B” school and 88,923 attended a "C" school in October 2011. The final analysis sample will be chosen from these 153,875 students, depending on the bandwidth selected for the RD analysis, which is explained in greater detail in the next section.

\footnotetext{
${ }^{3}$ The sample size reduction associated with excluding New Orleans schools is small because the majority of New Orleans schools were already excluded by the charter school screen.
} 


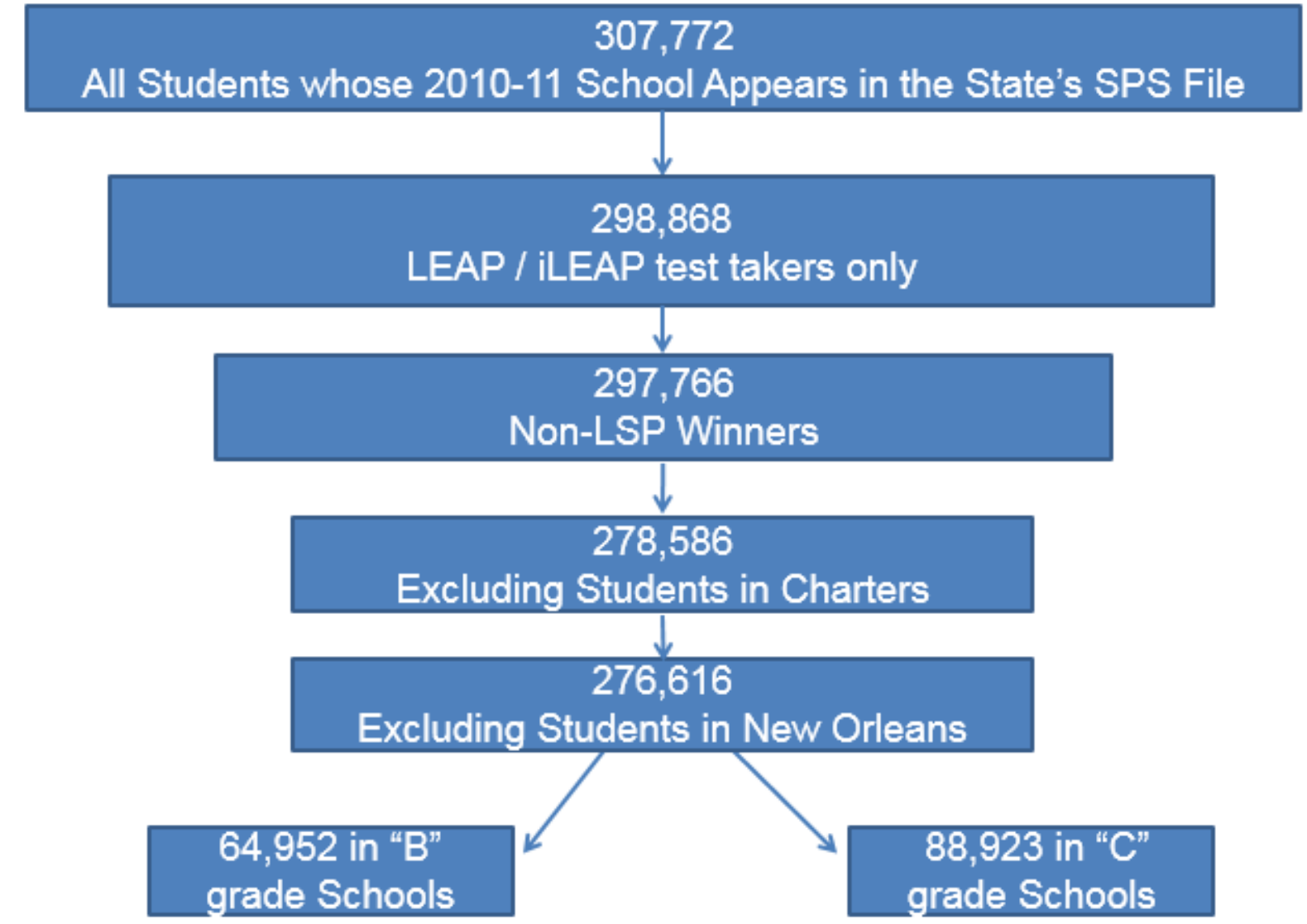

Figure 1. Sample Selection for the RD Analysis of LSP Competition on Public School Performance. 


\section{RD Research Design}

To estimate the competitive impact of the LSP, a reduced-form regression is used,

$$
\mathrm{A}_{\mathrm{ijt}}=\tau+\theta \mathrm{D}_{\mathrm{ijt}}+\rho\left(\mathrm{P}_{\mathrm{jt}}\right)+\omega_{1} \mathrm{X}_{\mathrm{ijt}}+\omega_{2} \mathrm{~S}_{\mathrm{jt}}+\zeta_{\mathrm{jt}}
$$

where $\mathrm{A}_{\mathrm{ijt}}$ is the average achievement of student $i$, in school $j$ in year $t ; \mathrm{D}_{\mathrm{ijt}}$ is an indicator for attending a school that experienced the threat of competition-i.e., it is a binary variable that takes on a value of one if the SPS score of the school attended is 105 or lower and zero otherwise $;{ }^{4} \mathrm{P}_{\mathrm{jt}}$ contains the school performance score (SPS) used to assign school grades; $\mathrm{X}_{\mathrm{ijt}}$ is a vector of student level covariates including lagged achievement, gender, race, limited English proficiency, free- or reduced-price lunch eligibility, special education status, and grade; $\mathrm{S}_{\mathrm{jt}}$ is a vector of school level covariates including school percent female/Black/Hispanic/special education/limited English proficient, and percent qualifying for free-or reduced-price lunch. Finally, $\zeta_{\mathrm{jt}}$ is an idiosyncratic error term. A quartic polynomial is included in $\mathrm{P}_{\mathrm{j} t}$, to control for the functional form of the SPS. The estimated impact of competition from private schools through the LSP, $\theta$, can be interpreted as causal under the assumption that, conditional on the school performance score, the assignment of grades is uncorrelated with the error term $\zeta_{\mathrm{jt}}$.

The strength of the RD is that it does not incorporate all eligible public schools—only a narrow set of schools above and below the 105-point SPS cut-off that distinguishes "C" schools from "B" schools. The more similar the SPS score of the "B" and "C" schools on either side of this cut-off, the more similar one might expect these schools to be in both observable and unobservable ways, strengthening the internal validity of the analysis. In selecting the width of

\footnotetext{
${ }^{4}$ The reader should note that none of the spatial measures of competition used thus far are reflected in this indicator.
} 
the "window" of observations to be used for the RD, I start by using the smallest bandwidth feasible, which is one point above and one point below the "B"/ "C" cutoff. I also experiment with using wider bandwidths of five and ten points above and below the cutoff, which allow me to incorporate a larger sample of students. Table 6 presents descriptive statistics of the samples of students in "high-C" treatment schools and "low-B" control schools, depending on the bandwidth selected. Although only 48 schools and 13,357 students are included in the sample when I select the one point trim, student characteristics between the treatment and control groups are most comparable when this bandwidth is applied. Specifically, $t$-tests confirm baseline equivalence between the two groups in terms of school type attended, gender, other race, LEP, and ELA standardized score. Thus, the primary RD findings will come from the sample with a 1point trim and will control for all of the characteristics reported in Table 6 as well as the school performance score which determined a school's letter grade. 
Table 6.

Descriptive Statistics for RD Analysis of the LSP

\begin{tabular}{|c|c|c|c|c|c|c|c|c|c|c|c|c|}
\hline & \multicolumn{4}{|c|}{$1 \mathrm{pt}$ Trim } & \multicolumn{4}{|c|}{ 5pt Trim } & \multicolumn{4}{|c|}{ 10pt Trim } \\
\hline & Treat. & Control & Diff. & $p$ & Treat. & $\begin{array}{c}\text { Contro } \\
1\end{array}$ & Diff. & $p$ & Treat. & $\begin{array}{c}\text { Contro } \\
1\end{array}$ & Diff. & $p$ \\
\hline Students & 6,893 & 6,464 & & & 29,504 & 32,584 & & & 62,647 & 52,908 & & \\
\hline Schools & 23 & 25 & & & 107 & 107 & & & 223 & 180 & & \\
\hline \multicolumn{13}{|l|}{ School Type } \\
\hline Elem/ Middle & 0.80 & 0.93 & $-0.13 * * *$ & 0.00 & 0.86 & 0.88 & $-0.03 * * *$ & 0.00 & 0.86 & 0.85 & $0.01 * * *$ & 0.00 \\
\hline Combination & 0.20 & 0.07 & $0.13 * * *$ & 0.00 & 0.14 & 0.12 & $0.03 * * *$ & 0.00 & 0.14 & 0.15 & $-0.01 * * *$ & 0.00 \\
\hline \multicolumn{13}{|l|}{ School Characteristics } \\
\hline Female & 0.50 & 0.49 & 0.01 & 0.12 & 0.50 & 0.49 & $0.01 *$ & 0.10 & 0.49 & 0.49 & 0.00 & 0.29 \\
\hline Special Education & 0.08 & 0.10 & $-0.02 * * *$ & 0.00 & 0.08 & 0.09 & $0.00 * *$ & 0.04 & 0.09 & 0.09 & 0.00 & 0.23 \\
\hline Black & 0.24 & 0.17 & $0.07 * * *$ & 0.00 & 0.25 & 0.18 & $0.07 * * *$ & 0.00 & 0.28 & 0.18 & $0.10 * * *$ & 0.00 \\
\hline Hispanic & 0.03 & 0.04 & $0.01 * * *$ & 0.00 & 0.03 & 0.04 & 0.00 & 0.66 & 0.04 & 0.03 & $0.00 * * *$ & 0.00 \\
\hline White & 0.69 & 0.75 & $-0.06 * * *$ & 0.00 & 0.67 & 0.75 & $-0.07 * * *$ & 0.00 & 0.65 & 0.75 & $-0.11 * * *$ & 0.00 \\
\hline Other Race & 0.04 & 0.04 & 0.00 & 0.34 & 0.04 & 0.04 & $0.01 * * *$ & 0.00 & 0.04 & 0.03 & $0.00 * *$ & 0.03 \\
\hline LEP & 0.02 & 0.02 & 0.00 & 0.34 & 0.01 & 0.01 & $0.00 * * *$ & 0.00 & 0.02 & 0.01 & $0.01 * * *$ & 0.00 \\
\hline Free Lunch & 0.58 & 0.54 & $0.04 * * *$ & 0.00 & 0.60 & 0.51 & $-0.09 * * *$ & 0.00 & 0.62 & 0.51 & $0.11 * * *$ & 0.00 \\
\hline \multicolumn{13}{|l|}{ Test Scores, 2010-11 } \\
\hline Average ELA Z Score & 0.12 & 0.13 & -0.01 & 0.57 & 0.07 & 0.16 & $-0.09 * * *$ & 0.00 & 0.04 & 0.18 & $-0.14 * * *$ & 0.00 \\
\hline Average Math Z Score & 0.09 & 0.13 & $-0.03 * *$ & 0.01 & 0.07 & 0.18 & $-0.11 * * *$ & 0.00 & 0.03 & 0.21 & $-0.17 * * *$ & 0.00 \\
\hline
\end{tabular}

Note: LEP = Limited English Proficient. 


\section{Results of RD Analysis}

I first present a graphical analysis of the regression discontinuity at the school level to see if a pattern emerges that can later be confirmed by the regression discontinuity analysis conducted at the student level. The null results for "C" schools from model (1) are confirmed, as there does not appear to be strong evidence of a competitive response in "C" schools. Figure 2 plots schoolaverage math and English language arts standardized scores against the "B" or "C" letter grade received. To aid with interpretation, these scatterplots include a locally weighted "Fan" regression line, which uses an Epanechnikov kernel function (Fan and Gijbels, 1996). Regressions are calculated separately for " $\mathrm{B}$ " and " $\mathrm{C}$ " schools and provide a weighted average of math and ELA performance for a given school performance score. Because the calculation of school letter grades was informed by proficiency rates on ELA and math assessments, one expects to see a relationship between the school performance score and the raw scale scores. As expected, school-level scores rise gradually within letter grade bands. There is a minor break between "B" and "C" schools in math outcomes in both years but nothing of significant magnitude to suggest any impact of competition on school performance. 
Standardized Scores, 2011
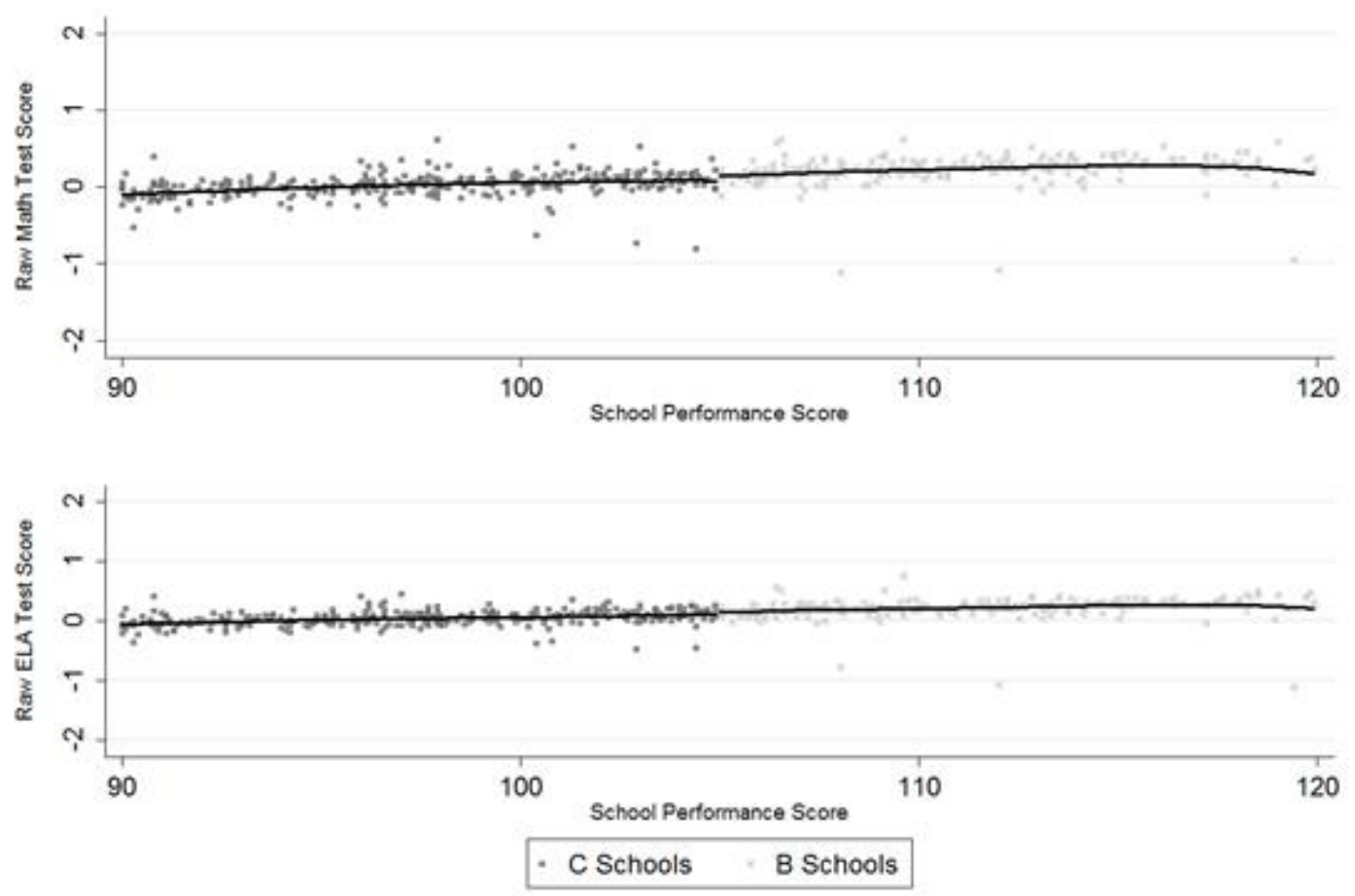

Standardized Scores, 2013
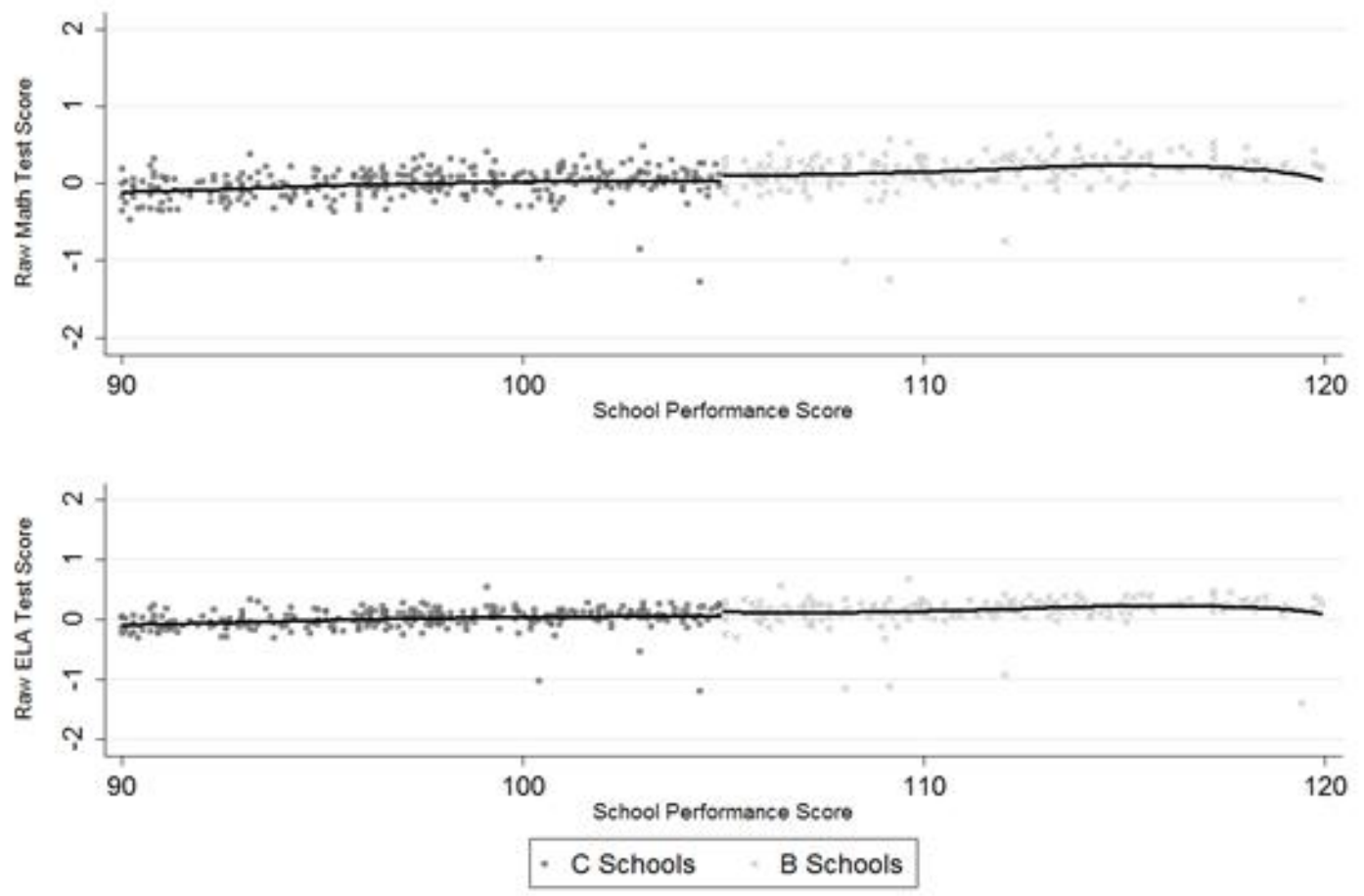

Figure 2. Louisiana Public Schools' Average Math and ELA Standardized Scores in 2010-11 and 2012-13, by "B" and "C" letter grades. The solid lines plot estimates from a locally weighted "Fan" regression line with a bandwidth of 5 points. 
Table 7 presents the results of student-level regressions in the form of equation (2). Standardized scores in ELA and math are regressed on the school performance score, an indicator for experiencing the threat of competition from the LSP (i.e., attending a "high-C" school), and student- and school-level demographic control variables. Standard errors are clustered at the school level. The first two columns display the results of the first placebo test in which I examine test scores from 2010-11, before the introduction of the LSP. I expect to find no significant differences in student outcomes, which is confirmed by the data. When I examine test scores from 2012-13, when the competitive threat was present, there is still no difference in test scores between "high-C" and "low-B" schools, conditional on the school performance score. As a robustness check and to maximize the power of the RD, I also increase the size of the bandwidth to five and ten points above and below the cut off to see if the inclusion of more observations alters the results, which it does not. I also experiment with including charter schools in addition to traditional public schools, and including schools in New Orleans but the indicator for competitive threat does not approach statistical significance in any of these specifications. 
Table 7.

The Impact of LSP Competition on Student Achievement, RD Results Comparing "High-C" (Treatment) to "Low-B" (Control) Schools

\begin{tabular}{|c|c|c|c|c|c|c|c|c|}
\hline & \multicolumn{2}{|c|}{2011 (Baseline) } & \multicolumn{4}{|c|}{2013} & \multirow{2}{*}{\multicolumn{2}{|c|}{ ELA }} \\
\hline & Math & ELA & \multicolumn{3}{|c|}{ Math } & \multirow[b]{2}{*}{ (6) } & & \\
\hline & (1) & (2) & (3) & (4) & (5) & & (7) & (8) \\
\hline "High-C" Schools & $\begin{array}{l}-.02 \\
(.02)\end{array}$ & $\begin{array}{l}-.05 \\
(.03)\end{array}$ & $\begin{array}{l}-.00 \\
(.04)\end{array}$ & $\begin{array}{l}-.02 \\
(.04)\end{array}$ & $\begin{array}{l}-.01 \\
(.03)\end{array}$ & $\begin{array}{c}.03 \\
(.03)\end{array}$ & $\begin{array}{l}-.01 \\
(.02)\end{array}$ & $\begin{array}{l}-.01 \\
(.02)\end{array}$ \\
\hline 1-Point Bandwidth & $\checkmark$ & $\checkmark$ & $\checkmark$ & & & $\checkmark$ & & \\
\hline 5-Point Bandwidth & & & & $\checkmark$ & & & $\checkmark$ & \\
\hline 10-Point Bandwidth & & & & & $\checkmark$ & & & $\checkmark$ \\
\hline Schools & 48 & 48 & 44 & 201 & 382 & 44 & 201 & 382 \\
\hline Observations & 10,435 & 10,438 & 8,610 & 39,202 & 70,859 & 8,612 & 39,205 & 70,863 \\
\hline \multicolumn{9}{|c|}{ Placebo Test: "A" v. "B" Schools } \\
\hline "High-B" Schools & & & $\begin{array}{l}-.08 \\
(.21)\end{array}$ & $\begin{array}{l}-.06 \\
(.06)\end{array}$ & $\begin{array}{l}-.03 \\
(.05)\end{array}$ & $\begin{array}{l}-.08 \\
(.16)\end{array}$ & $\begin{array}{l}-.05 \\
(.05)\end{array}$ & $\begin{array}{l}-.03 \\
(.03)\end{array}$ \\
\hline 1-Point Bandwidth & & & $\checkmark$ & & & $\checkmark$ & & \\
\hline 5-Point Bandwidth & & & & $\checkmark$ & & & $\checkmark$ & \\
\hline 10-Point Bandwidth & & & & & $\checkmark$ & & & $\checkmark$ \\
\hline Schools & & & 17 & 64 & 147 & 17 & 64 & 147 \\
\hline Observations & & & 3,513 & 12,443 & 25,413 & 3,511 & 12,441 & 25,410 \\
\hline \multicolumn{9}{|c|}{ Placebo Test: "C" v. "D" Schools } \\
\hline “High-D” Schools & & & $\begin{array}{l}-.09 \\
(.06)\end{array}$ & $\begin{array}{c}-.02 \\
(.04)\end{array}$ & $\begin{array}{l}-.02 \\
(.03)\end{array}$ & $\begin{array}{c}.04 \\
(.06)\end{array}$ & $\begin{array}{c}-.02 \\
(.03)\end{array}$ & $\begin{array}{l}-.02 \\
(.02)\end{array}$ \\
\hline 1-Point Bandwidth & & & $\checkmark$ & & & $\checkmark$ & & \\
\hline 5-Point Bandwidth & & & & $\sqrt{ }$ & & & $\checkmark$ & \\
\hline 10-Point Bandwidth & & & & & $\checkmark$ & & & $\checkmark$ \\
\hline Schools & & & 47 & 185 & 381 & 47 & 185 & 381 \\
\hline Observations & & & 8,268 & 29,669 & 63,802 & 8,269 & 29,667 & 63,803 \\
\hline
\end{tabular}




\begin{tabular}{|c|c|c|c|c|c|c|c|c|}
\hline & \multicolumn{3}{|c|}{2011 (Baseline) } & \multicolumn{5}{|c|}{2013} \\
\hline & Math & ELA & & Math & ELA & Math & ELA & \\
\hline \multicolumn{9}{|c|}{ Placebo Test: "D" v. "F" Schools } \\
\hline "High-F" Schools & & & $\begin{array}{l}.18 \\
(.14)\end{array}$ & $\begin{array}{c}.07 \\
(.11)\end{array}$ & $\begin{array}{l}-.06 \\
(.08)\end{array}$ & $\begin{array}{l}-.02 \\
(.09)\end{array}$ & $\begin{array}{c}.10 \\
(.07)\end{array}$ & $\begin{array}{c}.03 \\
(.05)\end{array}$ \\
\hline 1-Point Bandwidth & & & $\checkmark$ & & & $\checkmark$ & & \\
\hline 5-Point Bandwidth & & & & $\checkmark$ & & & $\checkmark$ & \\
\hline 10-Point Bandwidth & & & & & $\checkmark$ & & & $\checkmark$ \\
\hline Schools & & & 16 & 53 & 134 & 16 & 53 & 134 \\
\hline Observations & & & 2,820 & 6,744 & 20,244 & 2,819 & 6,739 & 20,234 \\
\hline
\end{tabular}

Note: Estimates presented in standard deviation units. Robust standard errors clustered at the school level in parentheses. All models include controls for lagged achievement, gender, race, limited English proficiency, free and reduced lunch eligibility, special education status, student grade, and school average measures of each of the demographic variables; Charter schools and New Orleans schools are excluded from this sample; $* * *$ significant at $\mathrm{p}<.01, * *$ significant at $\mathrm{p}<.05, *$ significant at $\mathrm{p}<.10$ 
Table 7 also displays the results of further placebo tests, which I conduct by running the $\mathrm{RD}$ with different school letter grade combinations. Instead of comparing "High-C" and "LowB" schools, I compare all other grade band combinations (i.e., "A" v. "B" schools, "C" v. "D" schools, and "D" v. "F" schools). None of the estimates in any of these models are statistically significant, increasing confidence in the validity of this approach.

\section{RD Analysis by Competitive Threat Level}

It is possible that the RD analysis includes many traditional public schools that do not have any realistic private school competitors in close proximity. Thus, even though their students become eligible for vouchers, the traditional public school administrators and teachers would be aware that there are no viable private school options for students to use a voucher to transfer to. If this is the case, it is possible the overall effect size is attenuated by the inclusion of such schools. In order to combine the best elements of the two distinct methodological approaches employed in this study, I identify those traditional public schools that experience high levels of competition, measured by the four geocoded competition measures described in (1). Specifically, I identify those public schools that experience the highest level of competitive threat by limiting the sample to just those observations that fall in the top third of the distributions of the four competition measures, which are all measured at baseline. In terms of distance, I limit the sample to public schools whose nearest competitor is less than 1.5 miles away. In terms of density, I limit the sample to public schools with 8 or more competitors within a 10-mile radius. In terms of diversity, I limit the sample to those public schools with 4 or more types of schools in a 10 mile radius. In terms of concentration, I limit the sample to those schools whose Herfindahl Index value is less than or equal to .35 . With this refined sample, I then re-run the RD analysis defined in (2), comparing "B"- and "C"- graded schools, right around the school performance 
score cut-off that determined which grade a school would receive. Table 8 displays the results of this follow-up analysis. 
Table 8.

The Impact of LSP Competition on Student Achievement, RD Results Focusing on Schools Facing High Levels of Competition

\begin{tabular}{|c|c|c|c|c|c|c|}
\hline \multicolumn{5}{|c|}{ Math } & \multicolumn{2}{|c|}{ ELA } \\
\hline & $(1)$ & $(2)$ & (3) & (4) & $(5)$ & (6) \\
\hline \multicolumn{7}{|c|}{ High Competition, Distance: Nearest Competitor is Less Than 1.5 Miles Away } \\
\hline "High-C" Schools & $\begin{array}{l}.42 * * \\
(.15)\end{array}$ & $\begin{array}{l}-.04 \\
(.06)\end{array}$ & $\begin{array}{l}-.04 \\
(.04)\end{array}$ & $\begin{array}{c}.22 * * * \\
(.06)\end{array}$ & $\begin{array}{c}.01 \\
(.04)\end{array}$ & $\begin{array}{l}-.01 \\
(.04)\end{array}$ \\
\hline 1-Point Bandwidth & $\checkmark$ & & & $\checkmark$ & & \\
\hline 5-Point Bandwidth & & $\checkmark$ & & & $\checkmark$ & \\
\hline 10-Point Bandwidth & & & $\checkmark$ & & & $\checkmark$ \\
\hline Schools & 11 & 54 & 96 & 11 & 54 & 96 \\
\hline Observations & 2,186 & 10,980 & 20,156 & 2,186 & 10,979 & 20,155 \\
\hline \multicolumn{7}{|c|}{ High Competition, Density: 8 or more Competitors within a 10 Mile Radius } \\
\hline "High-C" Schools & $\begin{array}{c}.04 \\
(.20)\end{array}$ & $\begin{array}{c}.03 \\
(.09)\end{array}$ & $\begin{array}{c}.02 \\
(.04)\end{array}$ & $\begin{array}{c}.32 * * * \\
(.06)\end{array}$ & $\begin{array}{c}.00 \\
(.07)\end{array}$ & $\begin{array}{l}-.02 \\
(.03)\end{array}$ \\
\hline 1-Point Bandwidth & $\checkmark$ & & & $\checkmark$ & & \\
\hline 5-Point Bandwidth & & $\checkmark$ & & & $\checkmark$ & \\
\hline 10-Point Bandwidth & & & $\checkmark$ & & & $\checkmark$ \\
\hline Schools & 12 & 51 & 87 & 12 & 51 & 87 \\
\hline Observations & 2,188 & 12,439 & 21,462 & 2,188 & 12,438 & 21,461 \\
\hline \multicolumn{7}{|c|}{ High Competition, Diversity: More than 4 Types of Schools in 10-Mile Radius } \\
\hline "High-C" Schools & $\begin{array}{l}.10^{* *} \\
(.04)\end{array}$ & $\begin{array}{c}.03 \\
(.08)\end{array}$ & $\begin{array}{l}-.03 \\
(.04)\end{array}$ & $\begin{array}{c}.10 \\
(.06)\end{array}$ & $\begin{array}{c}.03 \\
(.06)\end{array}$ & $\begin{array}{l}-.01 \\
(.03)\end{array}$ \\
\hline 1-Point Bandwidth & $\checkmark$ & & & $\checkmark$ & & \\
\hline 5-Point Bandwidth & & $\checkmark$ & & & $\checkmark$ & \\
\hline 10-Point Bandwidth & & & $\checkmark$ & & & $\checkmark$ \\
\hline Schools & 13 & 56 & 96 & 13 & 56 & 96 \\
\hline Observations & 2,299 & 14,596 & 23,749 & 2,299 & 14,597 & 23,750 \\
\hline
\end{tabular}




\begin{tabular}{|c|c|c|c|c|c|c|}
\hline & \multicolumn{3}{|c|}{ Math } & \multicolumn{3}{|c|}{ ELA } \\
\hline & $(1)$ & (2) & (3) & (4) & $(5)$ & (6) \\
\hline \multicolumn{7}{|c|}{ High Competition, Herfindahl Index Values Less Than .35} \\
\hline "High-C" Schools & $\mathrm{n} / \mathrm{a}$ & $\begin{array}{l}-.10 \\
(.10)\end{array}$ & $\begin{array}{l}-.09 \\
(.06)\end{array}$ & $\mathrm{n} / \mathrm{a}$ & $\begin{array}{c}.03 \\
(.04)\end{array}$ & $\begin{array}{c}.01 \\
(.03)\end{array}$ \\
\hline 1-Point Bandwidth & $\checkmark$ & & & $\checkmark$ & & \\
\hline 5-Point Bandwidth & & $\checkmark$ & & & $\checkmark$ & \\
\hline 10-Point Bandwidth & & & $\checkmark$ & & & $\checkmark$ \\
\hline Schools & & 34 & 56 & & 34 & 56 \\
\hline Observations & & 9,631 & 15,766 & & 9,635 & 15,770 \\
\hline
\end{tabular}

Note: Estimates presented in standard deviation units. Robust standard errors clustered at the school level in parentheses. All models include controls for lagged achievement, gender, race, limited English proficiency, free and reduced lunch eligibility, special education status, student grade, and school average measures of each of the demographic variables; Charter schools and New Orleans schools are excluded from this sample; $\mathrm{n} / \mathrm{a}$ indicates cells in which there were insufficient observations to generate estimates; $* * *$ significant at $\mathrm{p}<.01, * *$ significant at $\mathrm{p}<.05, *$ significant at $\mathrm{p}<.10$ 
The first panel displays the results of the competitive impact of the LSP on public schools whose nearest competitor is less than 1.5 miles away. There are null effects associated with the 10-point and 5-point bandwidth but when the sample is narrowed to just one point above and below the SPS cutoff, I find significant positive impacts on math achievement of 0.42 SD and on ELA achievement of $0.22 \mathrm{SD}$. The second panel displays the results of the competitive impact of the LSP on public schools with 8 or more competitors within a 10-mile radius. Again, there are null effects associated with the 10-point and 5-point bandwidth, but when the sample is narrowed to just one point above and below the SPS cutoff, I find significant positive impacts on ELA achievement of $0.32 \mathrm{SD}$. The third panel displays the results of the competitive impact of the LSP on public schools with more than 4 types of private school competitors in a 10-mile radius. As before, there are null effects associated with the 10-point and 5-point bandwidth, but when the sample is narrowed to just one point above and below the SPS cutoff, I find significant positive impacts on math achievement of $0.10 \mathrm{SD}$. The fourth panel displays the results of the competitive impact of the LSP on public schools with a Herfindahl Index less than or equal to 0.35. There are null effects associated with the 10-point and 5-point bandwidth and insufficient observations to examine effects when the sample is narrowed to a one-point bandwidth.

\section{Discussion}

The results presented in this article show that public school performance in Louisiana was either unaffected or modestly improved as a result of competition. In particular, those schools most affected by the program — the lowest-graded public schools, those that lost the greatest number of students per school, and those with realistic private school competition in their geographic area—had the largest response to the injection of competition. While some models reported null effects, positive impacts were observed particularly in math, ranging from .0012 to .4199 SD. 
Two empirical specifications are employed—a school fixed effects model that utilizes information about private school competition from geocoded measures of distance, density, diversity, and concentration of competition and a regression discontinuity design that tests whether students in "high-C" schools that are exposed to competition from the LSP realize greater performance gains than their peers in "low-B" public schools that are similar in many respects but are unaffected by competition from the program. The overall results from the school fixed effects analysis reveal null impacts in ELA and positive impacts in two out of four specifications in math. The RD estimates of a subsample of "C" and "B" schools find null effects across both Math and ELA.

While the overall effects observed in this analysis ranged from null findings to small positive effects, from a policy perspective, it is important to note that the largest effects were observed for those public schools that are located in those geographical areas in which students had realistic private school options after the voucher program's expansion. This finding raises important policy questions about the need to promote and maintain a high-quality, supply side response in the context of state-wide private school choice programs such as the LSP (Egalite, 2014; Kisida, Wolf, \& Rhinesmith, 2015). For instance, to attract high quality private schools to participate in such a program, policymakers need to consider the value at which to set the voucher value, whether or not to allow private schools to impose admissions restrictions on applications, and how to balance mandates for testing and reporting requirements with the desire for private schools to preserve autonomy.

There are a number of contextual factors that the reader should bear in mind when interpreting these results. First, this program was assessed in its first year of operation so the estimated effects could be underestimated if the voucher program did not have enough time to 
become sufficiently established to generate the type of competitive pressure that might prompt a clear public school response. Further, lawsuits filed against the program may have affected school administrators' perceptions of the permanency of the program, diluting any potential competitive pressure by giving the impression that the program could be quickly halted. For these reasons, it will be important to continue studying the systemic impacts of the LSP as later years of data become available.

Second, it is unclear how much power a traditional public school principal really has in order to respond to competition (Sullivan, Campbell, \& Kisida, 2008). In many schools, budget setting, policy development, and hiring decisions are made at the district level, leaving the principal with few assets to deploy in ways that might measurably impact student performance.

Third, this analysis examines student achievement on math and ELA standardized tests to judge the competitive impact of the LSP but public schools may respond to the competitive pressure of the LSP in other ways that are not captured by these test score gains and thus would not show up in this type of analysis. It could be the case that public schools focused on science, art, music, sports, or social studies as a mechanism to retain students who would be eligible for the voucher program. Alternatively, they could have responded to family preferences by offering more diverse electives, for example, or by conducting renovations on school facilities or taking active steps to better market their school (Holley, Egalite, \& Lueken, 2013). Furthermore, it might also be possible that the effects of competition might be felt in long-term outcomes such as improvements in student graduation rates or college enrollment if public schools respond to the competitive threat by sharpening their focus on attainment goals for students and cultivating an environment that prepares students for long-term success. 
Finally, this voucher program is means-tested, meaning it is designed to target lowincome students, not the universe of public school students. This feature of program design may significantly shape the public schools' perception of the program. It is even possible that public schools could be supportive of a program that attracts their poorest and possibly hardest-toeducate students. Instead of viewing this targeted voucher program as a threat to which they must respond, public schools may actually view it as a release valve and welcome the program as a positive outlet to which they can direct struggling students.

\section{Conclusion}

The findings from this competitive effects analysis of the LSP indicate that public school performance in ELA and math was either unaffected or modestly improved in response to competition from the LSP, particularly in those schools that experienced the strongest competitive threat. The primary contribution of this study is that it addresses the claim that voucher programs such as the LSP increase student performance by "lifting all boats" (Friedman, 1962; Hoxby, 2003). The results presented here are consistent with that hypothesis. The competitive threat of the LSP ranges from negligible to modestly positive in the public schools exposed to the threat of competition, with effect sizes growing in magnitude as the competitive threat looms larger. As large-scale school voucher programs continue to expand across the country, policymakers who are hopeful for the potential for market-based reforms to improve student outcomes across all sectors should be heartened by these findings. 


\section{References}

Altonji, J. G., Huang, C. I., \& Taber, C. R. (2015). Estimating the cream skimming effect of school choice. Journal of Political Economy, 123(2).

Anzia, S. F., \& Moe, T. M. (2013). Collective bargaining, transfer rights, and disadvantaged schools. Educational Evaluation and Policy Analysis, 36(1), 83-111.

Arce-Trigatti, P., Harris, D.N., Jabbar, Huriay, and Lincove, J.A. (2015). Many options in the New Orleans choice system. Education Next, 15(4): 25-33.

Bagley, C. (2006). School choice and competition: A public-market in education revisited. Oxford Review of Education, 32(3): 347-362.

Bowen, D. H., \& Trivitt, J. R. (2014). Stigmas without vouchers: The impact of ratings on student achievement in Florida's low-performing schools. Education Policy Analysis Archives.

Brunner, E. J., Imazeki, J., \& Ross, S. L. (2010). Universal vouchers and racial and ethnic segregation. The Review of Economics and Statistics, 92(4), 912-927.

Carnoy, M., Adamson, F., Chudgar, A., Luschei, T. F., \& Witte, J. F. (2007). Vouchers and public school performance: A case study of the Milwaukee Parental Choice Program. Washington, D.C.: Economic Policy Institute.

Carr, M. (2011). The impact of Ohio's EdChoice on traditional public school performance. Cato Journal, 31(2), 257-284.

Chakrabarti, R. (2013). Impact of voucher design on public school performance: Evidence from Florida and Milwaukee voucher programs. The B.E. Journal of Economic Analysis \& Policy, 13(1), 349-394.

Chakrabarti, R. (2008). Can increasing private school participation and monetary loss in a voucher program affect public school performance? Evidence from Milwaukee. Journal of Public Economics, 92(5-6), 1371-1393.

Chubb, J. E., \& Moe, T. M. (1990). Politics, markets, \& America's schools. Washington, D.C.: Brookings Institution Press.

Cohen-Vogel, L., \& Osborne-Lampkin, L. (2007). Allocating quality: Collective bargaining agreements and administrative discretion over teacher assignment. Educational Administration Quarterly, 43, 433-461.

Egalite, A. J. (2014). Choice program design and school supply. In M. Q. McShane (Ed.), New and better schools: The supply side of school choice (pp. 163-184). Lanham, MD: Rowman \& Littlefield Publishers, Inc.

Egalite, A. J., Jensen, L. I., Stewart, T., \& Wolf, P. J. (2014). Finding the right fit: Recruiting and retaining teachers in Milwaukee choice schools. The Journal of School Choice, 8(1), 113140 . 
Epple, D., \& Romano, R., E. (1998). Competition between private and public schools, vouchers, and peer-group effects. The American Economic Review, 88(1), 33-62.

Fan, J., \& Gijbels, I. (1996). Local polynomial modeling and its applications. London: Chapman and Hall.

Figlio, D., N., \& Hart, C., M.D. (2014). Competitive effects of means-tested school vouchers. American Economic Journal: Applied Economics, 6(1), 133-56.

Figlio, D., \& Rouse, C., E. (2006). Do accountability and voucher threats improve lowperforming schools? Journal of Public Economics, 92(1-2), 239-255.

Fiske, E. B., \& Ladd, H. F. (2000). When schools compete: A cautionary tale. Washington, D.C.: Brookings Institution Press.

Forster, G. (2008a). Lost opportunity: An empirical analysis of how vouchers affected Florida public schools. Friedman Foundation for Educational Choice.

Forster, G. (2008b). Promising start: An empirical analysis of how EdChoice vouchers affect Ohio public schools. Indianapolis, IN: The Friedman Foundation for Educational Choice.

Frendewey, M., Sawatka, K., Marcavage, W., Carney, K., Martinez, K, \& Dauphin, P. (2015). School choice yearbook 2014-2015: Breaking down barriers to choice. Washington, DC: Alliance for School Choice.

Friedman, M. (1962). Capitalism and freedom. Chicago, IL: University of Chicago Press.

Glomm, G., Harris, D., \& Lo, T. (2005). Charter school location, Economics of Education Review, 24(4), 451-457.

Gray, N. L., Merrifield, J. D., \& Adzima, K. A. (2014). A private universal voucher program's effects on traditional public schools. Journal of Economics and Finance, 1-26

Greene, J. P. (2001). An evaluation of the Florida A-Plus Accountability and School Choice Program (Civic Report). New York City: The Manhattan Institute for Policy Research. Retrieved from http://www.manhattan-institute.org/html/cr_aplus.htm.

Greene, J. P., \& Forster, G. (2002). Rising to the challenge: The effect of school choice on public schools in Milwaukee and San Antonio (Civic Bulletin No. 27). New York City: Manhattan Institute for Policy Research. Retrieved from http://www.manhattaninstitute.org/html/cb_27.htm.

Greene, J. P., \& Marsh, R., H. (2009). The effect of Milwaukee's Parental Choice Program on student achievement in Milwaukee public schools (No. 11). Fayetteville, AR: School Choice Demonstration Project, University of Arkansas. Retrieved from http://www.uark.edu/ua/der/SCDP/Milwaukee_Eval/Report_11.pdf.

Greene, J. P., \& Winters, M., A. (2004). Competition passes the test. Education Next, 4(3), 6671. 
Greene, J. P., \& Winters, M., A. (2007). An evaluation of the effect of DC's voucher program on public school achievement and racial integration after one year. Catholic Education: A Journal of Inquiry and Practice, 11(1), 83-101.

Greene, J. P., \& Winters, M., A. (2008). The effect of special education vouchers on public school achievement: Evidence from Florida's McKay Scholarship Program (Civic Report No. 52). New York City: The Manhattan Institute for Policy Research.

Harris, D. (2015). Good news for New Orleans. Education Next, 15(4): 8-15.

Herbermann, C. (1912). The Catholic encyclopedia: An international work of reference on the constitution, doctrine, discipline, and history of the Catholic Church. New York: Robert Appleton Company.

Hess, F. M. (2002). Revolution at the margins: The impact of competition on urban school systems. Washington, D.C.: Brookings Institution Press.

Holley, M., J., Egalite, A. J., \& Lueken, M., F. (2013). Competition with charters motivates districts. Education Next, 28-35.

Hoxby, C. M. (2001). Rising tide. Education Next, 1(4), 68-74.

Hoxby, C., M. (2003). School choice and school productivity (or, could school choice be a tide that lifts all boats?). In Hoxby, Caroline, M. (Ed.), The Economics of School Choice. Chicago, IL: University of Chicago Press.

Jabbar, H. (2015). Competitive networks and school leaders' perceptions: The formations of an education marketplace in post-Katrina New Orleans. American Educational Research Journal, 52(6): 1093-1131.

Kisida, B., Wolf, P. J., \& Rhinesmith, E. (2015). Views from private schools: Attitudes about school choice programs in three states. Washington, D.C.: American Enterprise Institute. Retrieved from https://www.aei.org/wp-content/uploads/2015/01/Views-from-PrivateSchools-7.pdf.

Lankford, H., \& Wyckoff, J. (2001). Who would be left behind by enhanced private school choice? Journal of Urban Economics, 50(2), 288-312.

Ladd, H., F. (2002). School vouchers: A critical view. Journal of Economic Perspectives, 16(4), $3-24$.

Ladd, H. F., \& Fiske, E. B. (2003). Does competition improve teaching and learning? Evidence from New Zealand. Educational Evaluation and Policy Analysis, 25(1), 97-112.

Loeb, S., Valant, J. \& Kasman, M. (2011). Increasing choice in the market for schools: Recent reforms and their effects on student achievement. National Tax Journal, 64: 141-63.

Lubienski, C. (2007). Marketing schools. Education and Urban Society, 40, 118-141 
Lubienski, C., Gulosino, C., \& Weitzel, P. (2009). School choice and competitive incentives: Mapping the distribution of educational opportunities across local education markets. American Journal of Education, 115, 601-647.

McCall, J. (2014, March 25). Lawmakers should keep public funds in public schools, The Sun Sentinel. Retrieved from http://articles.sun-sentinel.com/2014-03-25/news/fl-oped-schoolvouchers-20140325_1_public-schools-private-schools-rigorous-programs.

McMillan, R. (2000). Competition, parental involvement, and public school performance. National Tax Association Proceedings, 93, 150-155.

Merrifield, J., \& Gray, N. (2009). An evaluation of the CEO Horizon, 1998-2008, Edgewood Tuition Voucher Program. Washington, D.C.: Searle Freedom Trust and CEO Foundation.

Rich, M. (2014, Jan 27). Bill to offer an option to give vouchers, The New York Times. Retrieved from http://www.nytimes.com/2014/01/28/education/senator-to-propose-schoolvouchers-program.html? $\mathrm{r}=0$.

Rouse, C., Hannaway, J., Goldhaber, D., \& Figlio, D., N. (2013). Feeling the Florida heat: How low performing schools respond to voucher and accountability pressure. American Economic Journal: Economic Policy, 5(2), 251-81.

Ryan, J. \& Heise, M. (2002). The political economy of school choice.The Yale Law Journal, 111(8): 2043-2136.

Schneider, M., Teske, P., \& Marschall, M. (2000). Choosing schools: Consumer choice and the quality of American schools. Princeton, NJ: Princeton University Press.

Schneider, M., Teske, P., Marschall, M., \& Roch, C. (1998). Shopping for schools: In the land of the blind, the one-eyed parent may be enough. American Journal of Political Science, 42(3), 769-793.

Schrier, D. (2014, May 4). State funding of private schools threatens public education. The Ocala Star Banner. Retrieved from http://www.ocala.com/article/20140504/OPINION/140509905.

Sullivan, M. D., Campbell, D. B., \& Kisida, B. (2008). The muzzled dog that didn't bark: Charters and the behavioral response of D.C. public schools. Fayetteville, AR: University of Arkansas. Retrieved from http://files.eric.ed.gov/fulltext/ED508627.pdf.

Van Dunk, E., \& Dickman, A. (2002). School choice accountability: An examination of informed consumers in different choice programs. Urban Affairs Review, 37 (6): 844-856.

Weingarten, R. (2013, October 10). Two visions. The Huffington Post. Retrieved from http://www.huffingtonpost.com/randi-weingarten/two-visions_b_4131785.html.

West, M., R., \& Peterson, P., E. (2006).The efficacy of choice threats within school accountability systems. The Economic Journal, 116(510), 48-62. 
Winters, M., A., \& Greene, J. P. (2011). Public school response to special education vouchers: The impact of Florida's McKay Scholarship Program on disability diagnosis and student achievement in public schools. Educational Evaluation and Policy Analysis, 33(2), 138158. 


\begin{abstract}
About the Author
Anna J. Egalite is an Assistant Professor in the Department of Educational Leadership, Policy, and Human Development in the College of Education at North Carolina State University. She holds a Ph.D. in education policy from the University of Arkansas and an M.Ed. from the University of Notre Dame's Alliance for Catholic Education. She completed a postdoctoral fellowship in the Program on Education Policy and Governance at Harvard University. Her research focuses on the evaluation of education policies and programs intended to close racial and economic achievement gaps, such as the introduction of market forces into education through school choice and competition.
\end{abstract}

\begin{abstract}
About the SCDP
Housed within the Department of Education Reform at the University of Arkansas, the School Choice Demonstration Project (SCDP) is an education research center dedicated to the nonpartisan study of the effects of school choice policy. Led by Dr. Patrick J. Wolf, the SCDP's national team of researchers, institutional research partners and staff are devoted to the rigorous evaluation of school choice programs and other school improvement efforts across the country. The SCDP is committed to raising and advancing the public's understanding of the strengths and limitations of school choice policies and programs by conducting comprehensive research on what happens to students, families, schools and communities when more parents are allowed to choose their child's school. Reports from past SCDP studies are available at http://www.uaedreform.org/school-choice-demonstration-project/.
\end{abstract}

\title{
About ERA-NOLA
}

The Education Research Alliance for New Orleans is based within the School of Liberal Arts at Tulane University. The objective of ERA-New Orleans is to provide objective, rigorous, and useful research to improve schools in New Orleans and beyond. For more information about ERA-New Orleans, including some of the studies mentioned in this brief, please visit www.educationresearchalliancenola.com. 